\title{
Academic Civic Mindedness and Model Citizenship in the International Baccalaureate Diploma Programme
}

Anna Rosefsky Saavedra, the RAND Corporation

RAND Education

WR-1044-IBO

April 2014

Prepared for the International Baccalaureate Organization

RAND working papers are intended to share researchers' latest findings and to solicit informal peer review. This paper has been approved for circulation by the RAND National Security Research Division but has not been formally edited or peer reviewed. RAND working papers can be quoted and cited without permission of the author provided the source is clearly referred to as a working paper. RAND's publications do not necessarily reflect the opinions of its research clients and sponsors. RAND ${ }^{\circledR}$ is a registered trademark. 



\section{Preface}

The study described in this paper examines the International Baccalaureate (IB) Diploma Programme (DP)'s development of students' "academic civic mindedness" and "model citizenship" at four case study schools in California. Despite several national initiatives intended to increase U.S. public schools' emphasis on developing students' civic engagement and citizenship, most U.S. schools do not prioritize either objective. IB programmes are a widely implemented intervention - currently operating in 1,500 U.S. schools, over 90 percent of which are public - with a strong stated commitment to developing students' citizenship. Greater understanding of both the extent which the IB DP promotes students' citizenship and the means through which it does so could contribute to strengthening the effort to improve the current state of U.S. civic education. This understanding could also provide the IB Organization (IBO) with recommendations for how to improve its civic focus. The results of this study also contribute to the debate over whether a holistic educational philosophy that encompasses development of citizenship and complex thinking and communication skills is compatible with developing basic academic skills and knowledge. Finally, the survey developed to measure sample IB DP students' academic civic mindedness and model citizenship could be used to measure those constructs in other students.

This paper should be of interest to U.S. education policymakers and practitioners with concerns about the civic purposes of education and about developing the skills and knowledge students need for future success in college and career. It should also be of interest to IBO staff and others who are involved in IB programmes in the U.S. and elsewhere.

The research for this study was conducted within the Education Unit of the RAND Corporation. For more information about the RAND Education Unit, see http://www.rand.org/topics/education-and-the-arts.html or contact the Unit Director (contact information is provided on the web page). The International Baccalaureate Organization contracted with the RAND Education Unit to conduct the research presented in this report. 



\section{TABLE OF CONTENTS}

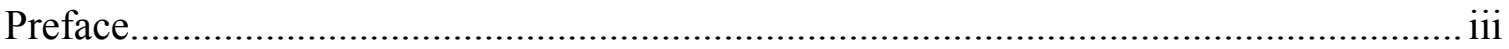

Acknowledgements ................................................................................................. vii

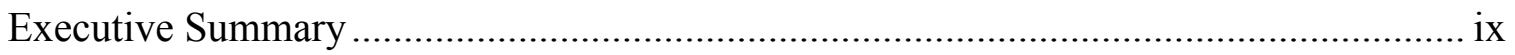

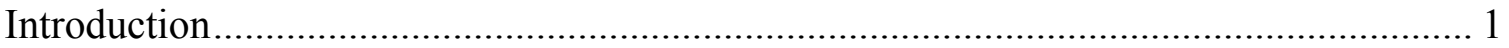

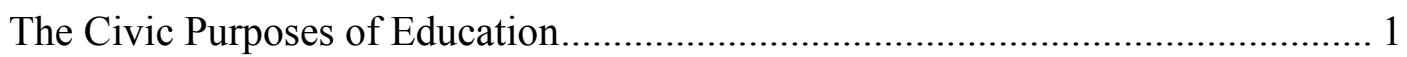

Definitions: "Academic civic-mindedness" and "model citizenship" ...................... 2

The International Baccalaureate Diploma Programme .............................................. 4

IB and broad-versus-narrow conceptions of education ........................................ 7

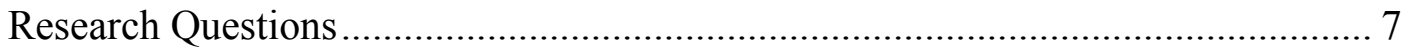

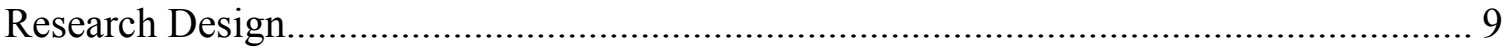

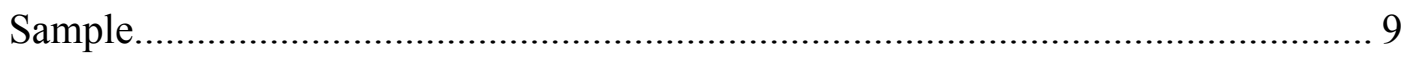

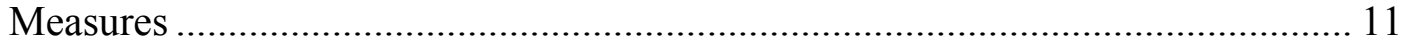

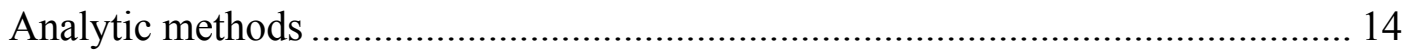

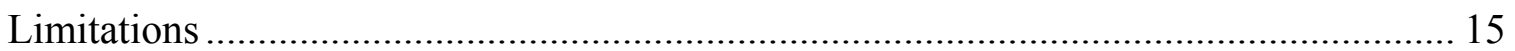

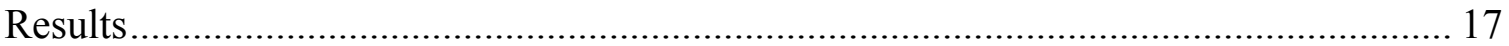

RQ \#1: Description of the student sample and differences between IB and non-IB

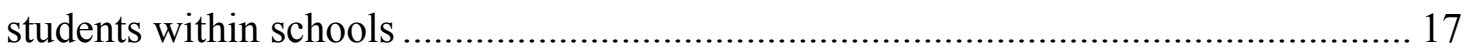

RQ \#2: IB DP development of students' academic civic mindedness.................... 18

RQ \#3: IB DP students' academic civic mindedness performance ........................ 23

RQ \#4: IB DP development of students' model citizenship ................................... 25

RQ \#5: IB compared to non-IB alternatives ...................................................... 30

RQ \#6: Barriers to emphasis on civic mindedness and model citizenship ............. 32

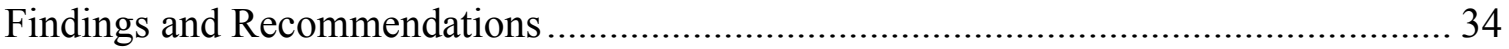

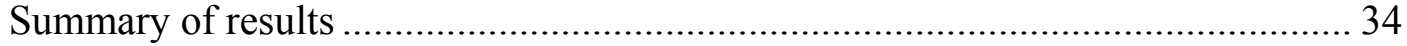

Implications for all educators concerned with the civic purposes of education ..... 36

Recommendations for the IB Organization ........................................................ 36

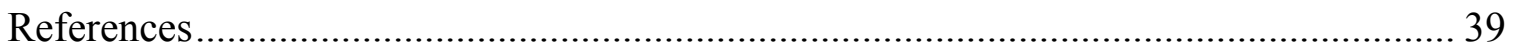

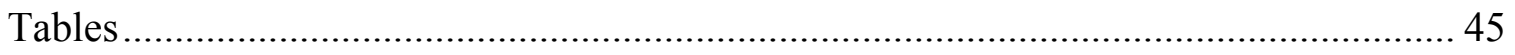

Appendix A: Student interview protocol ................................................................... 59

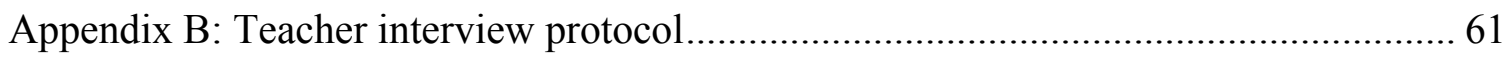

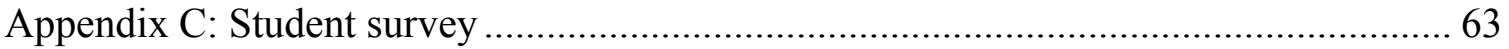

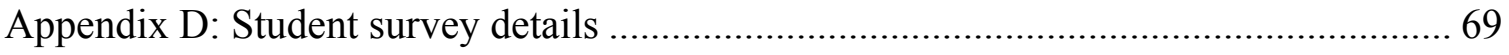





\section{Acknowledgements}

I would like to thank the International Baccalaureate Organization (IBO) for its support of this paper and particularly IBO program officer Liz Bergeron for her comprehensive guidance. IBO staff Mandy Newport, Alison Smith and Dandan Wang also provided invaluable survey support for which I am very grateful. Thank you as well to Kei Kawashima-Ginsberg and Peter Levine from the Center for Information and Research on Civic Learning and Engagement for generously sharing their 2012 voting survey data. I am also very appreciative of study design advice from Keith Barton, Diana Hess and Joseph Kahne. Thank you especially to Kim Hui for her excellent research assistance. In addition, the paper benefited substantively from a RAND quality assurance review by Cathy Stasz. 



\section{Executive Summary}

Originally founded as a private means for diplomats' children to earn an internationally recognized high school diploma, today the International Baccalaureate (IB) Diploma Programme (DP) serves students from a variety of backgrounds in 144 countries. In the U.S., 1,500 schools offer IB programmes, over 90 percent of which are public, to kindergarten through twelfth grade students, including 807 that offer the DP. In schools that the IB Organization (IBO) authorizes as "IB World Schools" to offer the IB DP, teachers use standardized IB curriculum and pedagogy to teach a range of courses and to offer other activities that are intended to prepare IB-enrolled students for college and citizenship.

The IB mission is to, "develop inquiring, knowledgeable and caring young people who help to create a better and more peaceful world through intercultural understanding and respect" (IBO, 2009a, 5). The purpose of the IB Learner Profile-consisting of ten ideal qualities to foster in students - is to provide schools and teachers with a practical means through which to translate the IB mission into practice. IB explicitly prefaces the ten attributes with the overarching principle of "educating the whole person for a life of active, responsible citizenship" (IBO, 2008a, p.1), suggesting that development of students' citizenship is the core purpose of an IB education. The Learner Profile is central to the curricular model and reflects "the concern with developing competent, caring and active citizens as well as subject specialists" (IBO, 2009a, p.2). Again, this language emphasizes the centrality of citizenship to IB. The IB Learner Profile prefaces every IB course-specific guide, as the overarching purpose of every course is to develop the ten attributes in students.

In this study, in the U.S. context, I investigate IB DP development of students' "academic civic mindedness" and "model citizenship" using a case study methodology. This study follows the definition of "academic civic mindedness" as, "student knowledge of the U.S. system of government, ${ }^{1}$ public policy and effective advocacy techniques" (IBO, 2013, p.1). This paper adopts the term "model citizenship" following the Westheimer \& Kahne (2004) citizen typology that includes participatory, personally responsible and social justice citizenship orientations.

In four public schools located in the state of California that offer the IB DP, I interviewed IB DP Coordinators, teachers $(n=15)$ and students $(n=24)$ to learn their perspectives about how and the extent to which the IB DP prepares students for citizenship. To supplement the qualitative understanding of the relationship between

${ }^{1}$ U.S. government in the U.S. context. 
students' enrollment in the IB DP and their civic mindedness and citizenship, I also surveyed students using items focused on measuring civic mindedness and citizenship that were administered as part of other surveys to large samples of high school-enrolled 17 and 18 year olds. Given the small sample size and other limitations, the results are suggestive rather than definitive and further research is needed to confirm the findings.

\section{Results}

The results indicate that the DP's heavy pedagogical reliance on discussions, debates, oral presentations, written assignments and teamwork, enables students to develop many of the complex thinking and communication (Levy \& Murnane, 2004) skills that are necessary for civic advocacy. For example, the DP emphasis on seeking, considering, weighing and synthesizing different perspectives, particularly through the Theory of Knowledge (TOK) course, seems to develop students' critical thinking, objectivity, openmindedness and ability to compromise. Further, the list of skills that students and teachers believe are necessary for civic engagement overlaps to a significant extent with most lists of skills that students need for success in college and careers. IB could, however, be more intentional to teachers, and teachers in turn to students, about the civic applications of these skills.

Results also indicate that the IB DP places a strong emphasis on students' knowledge of issues related to public policy, particularly through discussions of current events in TOK, English and History courses. Teacher and student interview results indicate that the IB DP does not seem to strongly prioritize students' knowledge of U.S. government structure and functioning. The student survey results, however, show that compared to nationally representative samples of similarly aged $12^{\text {th }}$-grade students, the sample of IB students scored higher on nine of ten items that tested their knowledge of U.S. government history and functioning.

Though the data suggests that individual teachers and students relate to several citizenship orientations simultaneously, teachers seem to most frequently identify with participatory, followed by social justice and then personally responsible citizenship. Student survey and interview results indicate that they most strongly relate to the social justice type, followed by personal responsibility and then participatory citizenship. The IB DP develops students' model citizenship through promoting their awareness of political and social issues and required active engagement with a local or global issue. Several structural features of the IB DP may also develop the attitudes students deem necessary for civic engagement.

In the schools included in the study, alternatives to courses offered through the IB DP primarily include Advanced Placement (AP) and California Prep (CP) courses. Like the IB DP, AP courses also have a rigorous college preparation reputation while the $\mathrm{CP}$ courses are not honors level and are intended for students with average or below average 
academic backgrounds. Most IB students and teachers feel that IB DP develops students' academic civic mindedness and model citizenship to a considerably greater extent.

Finally, teachers feel that the strongest limitation to their prioritization of students' citizenship development is their lack of clarity on how to frame the civic implications of the knowledge, skills and attitudes they seek to develop. Teachers also feel that limited student skills and lack of Diploma examination questions' emphasis on citizenship also challenge their civic focus.

\section{Recommendations}

The main implications of the findings are:

For the greater community of civic education researchers and practitioners:

1) The skills that educators, parents and employers believe are necessary for success in college and career overlap substantially with the skills that students and teachers in this study believe are necessary for civic engagement. As part of efforts to increase schools' civic focus, it might behoove the civic education community to emphasize this message to teachers, including the need to be explicit with their students about the overlap.

2) The DP's emphasis on seeking, considering, weighing and synthesizing different perspectives, particularly through the TOK course, might be a useful model for other educators to follow as a means of developing students' critical thinking, objectivity, openmindedness and ability to compromise.

3) The carefully structured "best-case" model of the Creativity, Action and Service (CAS) course demonstrates promise as a means of developing the knowledge, skills and attitudes that students need for civic engagement.

4) The survey developed to measure sample IB DP students' academic civic mindedness and model citizenship could be adapted to measure those constructs in other (IB or non-IB) students.

For the IB Organization and U.S. IB schools:

1) The IB Organization (IBO) could be more intentional in their curricular and pedagogical materials and through professional development (PD) in explaining to teachers the connections between the DP requirements and civic mindedness and citizenship. Greater IBO intentionality could increase emphasis on developing students' academic civic mindedness and model citizenship across IB World schools and reduce cross-school variation.

2) The IBO could be more explicit to teachers about the overlap between the knowledge, skills and attitudes necessary for civic engagement and for college 
and career preparation so that teachers internalize and share that message with students.

3) The IBO could consider strengthening teachers' accountability for developing students' civic mindedness and citizenship through greater Diploma examination focus on evaluating students' academic civic mindedness and model citizenship.

4) The IBO could help to improve the CAS program by providing schools with more detailed guidance on the best ways to structure it.

5) In addition to making citizenship connections more explicit through subjectspecific materials and PD, the IBO could consider offering PD sessions that deepen teachers' understanding of their own civic orientations.

6) Finally, the survey developed to measure sample IB DP students' academic civic mindedness and model citizenship could be used to measure those constructs in other IB DP students. 


\section{Introduction}

Originally founded as a private means for diplomats' children to earn an internationally recognized high-school diploma, today the International Baccalaureate (IB) Diploma Programme (DP) serves students from a variety of backgrounds in 2,470 schools spread across 144 countries and is one of the fastest growing education innovations in schools worldwide. In schools that are authorized to offer the DP by the IB Organization (IBO), teachers are trained to use standardized IB curriculum and pedagogy to teach a range of courses and to offer other activities that are intended to prepare IBenrolled students for college and citizenship. As of 2014, 1,500 U.S. schools-over 90 percent of which are public - offer IB programmes for K-12 students, including 807 that offer the DP.

In the introduction, I first provide background on the current state of civic education in the U.S. and define the "academic civic mindedness" and "model citizenship" constructs. Next I provide background on the IB DP as a means of developing students' civic mindedness and citizenship based on a selection of IB DP curricular documents.

\section{The Civic Purposes of Education}

Historically, public education has served as the primary means through which to develop students' capacities and inclinations to function effectively as citizens. In the U.S. context, educational forefathers including Webster, Jefferson, Dewey and Hutchins believed that education should shape and strengthen democratic society and fashioned schools to accomplish these ends (Ravitch \& Viteritti, 2001). By 1984, however, the focus of the influential publication, "A Nation at Risk," signified a shift away from the civic purpose of education toward the economic purpose of education (Reuben, 2005). By 2014, there is a strong case to be made that U.S. schools do not sufficiently prioritize the civic purposes of education (e.g., Campbell, Levinson and Hess, 2012; Gardner, 2006; Nussbaum, 2010), that Americans are decreasingly engaged in the civic sphere (Keeter, Zukin, Andolina, \& Jenkins, 2002; Putnam, 2000) and that there is an inequitable civiceducation gap between advantaged and disadvantaged students (Kahne \& Middaugh, 2008; Levinson, 2012a; Levinson, 2012b). Greater understanding of educational interventions that focus on promoting students' civic knowledge, engagement and citizenship - and subsequent increased use of those interventions that are found to be effective-could serve to attenuate these concerns. 


\section{Definitions: "Academic civic-mindedness" and "model citizenship"}

The crucial first step of this study is to clarify the meanings of "academic civicmindedness" and "model citizenship."

\section{"Academic civic mindedness"}

The IBO's "academic civic mindedness" construct is defined in the study research request as, "student knowledge of the U.S. system of government public policy and effective advocacy techniques" (IBO 2013, p. 1). This definition assumes that students need civic knowledge and skills to embrace their civic rights and responsibilities. In support of this assumption, in their seminal work on the American public's knowledge of politics, Delli Carpini \& Keeter (1997) demonstrate that democracy functions best when its citizens are politically informed. A broadly and equitably informed citizenry helps assure a democracy that is both responsive and responsible. From this perspective it is highly problematic that youth and adult political knowledge today is lower than it was several decades ago, even though education levels have risen considerably and there is much greater access to information through expansive media options (Niemi, 2012).

Though assessment of academic civic knowledge can gauge students' ability to engage as citizens, it is not sufficient for measuring engagement. Civic knowledge can be a foundation for engagement, but it is not necessarily the case that an individual who is very civically involved will do well on a civic knowledge test. Another concern with sole reliance on a measure of academic knowledge as a proxy for civic engagement is that knowledge tests can be little more than reading tests. For example, testing understanding of "bicameralism" is a test of vocabulary. And in the age of Google, with politics or any topic, it is often more important to know how to find information than to know it. Similarly, while it may be important to possess skills that could be used for civic engagement - like the ability to organize and run a meeting, express views in front of a group of people, organize a petition or contact an elected official-engagement may not happen in the absence of motivation to harness those skills for civic purposes.

\section{"Model citizenship"}

The idea of citizenship means different things to different people. Correspondingly there is a great deal of variation in the goals of civic education and the methods used to develop a certain type of citizen. For example, throughout history, democracies and fascist regimes have employed civic education with the purpose of developing markedly different types of citizens. Civic education to promote democratic principles might include activities that require deliberation and debate, while civic education to promote fascist ideals might promote obedience and order. 
Consensus around a singular definition of model citizenship will probably always remain unresolved. For example, in the U.S. historical context, according to Thomas Jefferson, the model citizen is an educated white man who can protect his rights and who knows enough to function as a part of the economy and social discourse (Jefferson, 1856). Horace Mann defines the model citizen is someone who is educated beyond the scope of utilitarian knowledge and virtuous according to Protestant ethics (Mann, 1891). More recently, Amy Gutmann argues that model citizens are mutually respectful, have faith in the democratic system and demonstrate civility, tolerance and ability to see issues from multiple perspectives (Gutmann, 2000). Indeed there are many ways in which one person's "model" might differ from another's with regard to learning attitudes, morals, character, identity, respect for others, critical thinking, knowledge, concern for oppressed people and so forth. Consequently, answers to the question "To what extent does Program $\mathrm{X}$ develop model citizens?" necessarily engage the political views that surround varied conceptions of citizenship. Any examination of civic education must first consider the type of citizen the educational experience seeks to develop.

To address this challenge, this study adopts the Westheimer \& Kahne (2004) citizen typology framework as a way to conceive of different types of model citizenship. In their empirical study of ten civic education programs, Westheimer and Kahne (2004) found that some programs place the greatest emphasis on fostering the ability and/or the commitment to participate, others encourage personal responsibility and others may prompt critical analysis that focuses on macro structural issues, the role of interest groups, power dynamics, and/or social justice.

Westhemer and Kahne (2004) suggest that engaged citizens can be participatory, personally responsible and/or justice-oriented. In the U.S. context, participatory citizens vote and help others to vote, write letters to the editor, peacefully protest and engage in other activities aimed at fostering democracy. Personally responsible citizens may follow laws, perform acts of community service, stay out of debt and generally behave in a way that conforms to the status quo. Finally, justice oriented citizens seek to reduce inequality and prejudice, promote human rights and represent diverse perspectives.

A given program, curriculum or pedagogy may seek to develop one or more of these citizenship types (Westheimer \& Kahne, 2004). My review of state-level social studies standards and curriculum frameworks suggests that civic education that promotes participatory citizenship is by far the most common form of civic education, followed by promotion of personal responsibility and then social justice at a distant third (Education Commission of the State, 2011).

Although this taxonomy has its limitations, the three-pronged conception of the conceivable purposes of civic education can serve as a lens through which to understand the citizenship focus of the IB Diploma Program. 


\section{The International Baccalaureate Diploma Programme}

The IB school-level authorization process and subsequent requirements for students and teachers are rigorous (Byrd, Ellington, Gross, Jago, \& Stern, 2007; Mathews \& Hill, 2005; U.S. Department of Education, 2011, 29). To earn DP authorization from the IB Organization (IBO), schools must demonstrate adherence to IBO's requirements as stated in the most current version of the "Handbook of procedures for the Diploma Program" (IBO, 2012). Typically, the IB accreditation process requires extensive faculty and staff participation, takes several years to complete and, if successful, results in authorized "IB World School" status. IB World-School DP teachers must use IB curricular and pedagogical materials to teach IB courses, and participate in ongoing PD and self-review processes.

U.S students enroll in the official IB DP in eleventh grade. To be eligible to earn the IB Diploma, students must successfully complete required IB courses at standard or higher levels - distinguished by hours spent per course and level of difficulty - in six subject groups: 1) Language and Literature, 2) Language Acquisition, 3) Experimental Sciences, 4) the Arts, 5) Mathematics and Computer Science and 6) Individual and Societies. Depending on the availability of courses by school, students take a course in each area at either the standard (150 teaching hours) or higher (240 teaching hours) level. For Diploma eligibility, students must take at least three and not more than four subjects at the higher level and successfully complete the IB Theory of Knowledge (TOK) epistemology course; participate in the weekly Creativity, Action and Service (CAS) requirement; and write a 4,000-word Extended Essay (EE). They must also score above defined thresholds on IBO-created and administered examinations in six subjects including languages, social studies, experimental sciences and mathematics. Nine thousand IB-certified examiners, in 121 countries worldwide, score the examinations (IBO, 2009a).

In a 2008 survey, 96 percent of IB DP Coordinators at 105 Title 1 schools reported that developing students' civic responsibility was an important or very important reason for choosing to implement the DP (Siskin, 2008). Despite the widespread belief that IB enrollment promotes students' civic responsibility and the implications of evidence supporting or refuting this claim, no empirical studies have investigated the relationship between the entirety of the IB DP experience and students' academic civic mindedness and citizenship. One study, set in a single school in Lesotho, Africa, investigates the relationship between enrollment in IB and students' civic responsibility (Kulundu \& Hayden, 2002). The authors find that 70 percent of IB students believe that the service component of the CAS course developed their sense of responsibility to the community, which is a fairly narrow sub-construct of a broader conception of citizenship. A second study compares development of young students' global citizenship - a construct related 
to yet different from the academic civic mindedness and model citizenship constructs - at IB and Montessori schools (Brunold-Conesa, 2010). The most recent study, set in Argentina, Canada and the U.S., examines the relationship between DP students' participation in CAS and their conceptualization of "civic-mindedness," motivation to serve their communities and perceived impacts on personal qualities (Biling \& Good, 2013). This multiple-country study finds that IB DP students engage in a wide range of service activities and serve their communities for altruistic reasons, though they do not have a clear understanding of "civic-mindedness." The study also reports that IB DP students and Coordinators believe that CAS helps students develop their commitment to service, self-confidence, maturity, open-mindedness and reflective abilities.

The present study builds on the 2013 Biling \& Good research by considering the IB DP more holistically, moving beyond CAS to investigate the extent to which IB curriculum, pedagogy and classroom and school climate may develop student's academic civic mindedness and model citizenship.

\section{How the IB DP might promote civic engagement}

The IB mission is to, “develop inquiring, knowledgeable and caring young people who help to create a better and more peaceful world through intercultural understanding and respect." This mission suggests that the IB conception of the good citizen is someone who actively engages with his/her surroundings (participatory) to improve and make the world more peaceful.

The purpose of the IB Learner Profile is to provide schools and teachers with a practical means through which to translate the IB mission into practice. The Learner Profile consists of ten attributes to foster in IB students, including that students be inquiring, knowledgeable, thinking, communicating, principled, open-minded, caring, risk-takers, balanced and reflective. Each of these attributes could relate to each of the three citizen types as defined in Westheimer and Kahne's typology. IB explicitly prefaces the tens with the overarching principle of "educating the whole person for a life of active, responsible citizenship" (IBO, 2008a, p.1), suggesting that development of students' citizenship is the core purpose of an IB education. The Learner Profile is central to the curricular model and reflects, "the concern with developing competent, caring and active citizens as well as subject specialists" (IBO, 2009a, p.2). Again, this language emphasizes the centrality of citizenship to IB. Another way to understand the Learner Profile is as a definition of IB's culture.

The IB Learner Profile prefaces every IB course-specific guide, as the overarching purpose of every course is to develop the ten attributes in students. Course-specific guidelines do not explicitly enumerate development of students' civic engagement, but refer to students' civic development using suggestive language. For example, the "Information Technology for a Global Society," (ITGS) (IBO, 2010, p.4) course 
overview states that the "increasingly widespread use of information technology inevitably raises important questions with regard to the social and ethical considerations that shape our society today. ITGS offers an opportunity for a systematic study of these considerations..." A conceivable implication once students are better informed about social and ethical considerations of technology is that they will understand the social justice implications of unequal distribution of technology and/or that they will be better informed to participate civically in issues regarding information technology.

The Economics course overview states, "If all participants in the global economy are to achieve a better quality of life for their populations, there must be economic cooperation between all countries" (IBO, 2007, p. 9). The concern for achieving a better quality of life for all populations suggests a social justice conception of citizenship.

The History overview asserts that the course:

"Provides a sound platform for the promotion of international understanding and, inherently, the intercultural awareness necessary to prepare students for global citizenship. Above all, it helps to foster respect and understanding of people and events in a variety of cultures throughout the world" (IBO, 2009b, p. 4).

Again, this course overview suggests a form of civic education dedicated to promoting students' participation and concern for social justice.

The Service component of the core Creativity, Action and Service (CAS) program is another means through which IB purports to address the civic objectives enumerated in the Learner Profile. The IBO describes the Service requirement as "an unpaid and voluntary exchange that has a learning benefit for the student," the purpose of which is to "develop a 'will to act' and the skills and values necessary to make a positive contribution to society" and asserts that one of the key CAS objectives is for students to be "aware of themselves as members of communities with responsibilities towards each other and the environment" (IBO, 2008b, p. 5). Unlike the Learner Profile and course overviews, the Service requirement seems to promote the conception of the personally responsible citizen to a somewhat greater degree than the participatory or social-justice orientations discussed earlier. The degree of latitude in the projects that students can pursue, however, suggests that it would be most accurate to say that CAS's benefits are variable across students. If a student identifies with participation, personal responsibility or social justice more strongly, he or she has the opportunity to pursue a CAS project that aligns with that aim.

The IB mission and Learner Profile broadly relate to all three of the citizen types identified in the taxonomy. The selected course overviews suggest that the IB Diploma Program stresses participatory and social justice conceptions of civic education. The service component of CAS could develop students' personal responsibility, participation and/or social justice orientation. In sum, IBO documents suggest that the DP could 
educate students in terms of all three conceptions of civic engagement.

\section{IB and broad-versus-narrow conceptions of education}

Another reason to examine academic civic-mindedness and citizenship in the IB DP is to contribute to the debate over whether more narrowly conceived academic achievement goals and broader conceptions of the educated child are compatible. There is a longstanding educational debate between i) proponents of a narrower educational focus on building students' basic reading, writing and math skills (i.e. Hirsch, 1987) and ii) more progressive, whole-child supporters, who believe that the purposes of education more broadly defined include building students' civic competencies, guiding their character development, developing their leadership capacity, stimulating their ability to ask good questions and so forth (i.e. Gardner, 2006; Perkins, forthcoming). This debate necessarily encompasses many shades of gray. For example, "narrow-focus" supporters believe that education ought to prepare students to participate effectively in civil society, not solely to demonstrate success in recall tests. "Broad-focus" advocates believe students must master basic skills.

IB occupies a middle space in this debate. On the one hand, a clear set of standards, testing and associated external accountability systems serve as the foundation for the DP. On the other, the DP curriculum broadly encapsulates first and second languages, social and physical sciences, mathematics and arts, as well as epistemology, intensive research and writing and service to the community, and promotes development of a range of core attributes through the IB Learner Profile (see Conner, 2008 for discussion of this idea).

A fairly robust literature base (i.e. Caspary, 2011; Coates et al, 2007; Coca et al, 2012; Culross \& Tarver, 2008; Higher Education Statistics Agency, 2011), including a causal study (Saavedra, 2014), indicates that IB DP enrollment increases students' academic outcomes. By investigating the IB DP's development of citizenship, a "non-academic" outcome, this paper seeks to contribute empirical evidence to this current debate.

\section{Research Questions}

Currently, policy makers, administrators, teachers, parents and students lack an empirically-based understanding of the relationship between the IB DP packageincluding curriculum, pedagogy and culture - and students' development of "academic civic-mindedness" and "model citizenship." Results will provide the IBO with understanding of the extent to which it is realizing its civically oriented goals. It will also provide potential consumers of the IB DP — students, parents, educators, university admissions officers, policy makers and others concerned with students' civic engagement-with information they can use to inform decisions about future investments in the IB DP. Finally, it will provide the greater community of civic education 
researchers, practitioners, policy makers and advocates with information with which to strengthen the movement to reintegrate the civic purposes of education in U.S. schools. To address the gap in understanding of the civic value of the IB DP and to contribute policy-relevant information to the IBO, potential IB DP program consumers and the greater civic education community, this study addresses the following research questions:

RQ \#1: What are the differences, if any, within schools between IB DP and non-IB DP students in terms of level of socio-economic advantage and academic background?

RQ \#2: To what extent and how does the IB DP curriculum, pedagogy and culture promote development of students' academic civic mindedness?

RQ \#3: How do IB DP students perform on measures of academic civic mindedness?

RQ \#4: How do IB DP teachers and students conceive of model citizenship? To what extent and how does the IB DP curriculum, pedagogy and culture promote development of students' model citizenship?

RQ \#5: How do IB DP teachers and students characterize differences between IB and non-IB courses regarding the extent to which and how each develops students' academic civic mindedness and model citizenship?

RQ \#6: What challenges limit teachers' ability to prioritize development of IB DP students' academic civic mindedness and model citizenship?

The next section of the paper describes the research methods employed to address these questions. 


\section{Research Design}

The research employs a mixed-methods approach that focuses on IB DP instruction and student outcomes at four schools that offer the IB DP in the state of California. I use semi-structured teacher and student interview methods to address all of the research questions and a student survey to address the second, third, fourth and fifth research questions.

\section{Sample}

California, with a majority-minority, 25 percent foreign-born population and over 40 percent of households speaking a language other than English, is among the most racially and culturally diverse state in the U.S. (U.S. Census, 2011). From a sheer numbers perspective, California is an ideal state in which to conduct this study. Of 807 U.S.-based IB DP's operating in 2014, 89 (11 percent) are offered in California IB World Schools and overall, approximately 1 in 8 U.S. students is educated in California schools.

Since civic education opportunities are greater and students' civic outcomes are stronger at more advantaged schools compared to less advantaged schools (Levinson, 2012b, Kahne \& Middaugh, 2008), the primary consideration for selection into the school sample was to include a range of average levels of student body socio-economic (SES) advantage. In consultation with the IBO, I selected schools that serve a range of student body proportions that are eligible to receive free or reduced price lunch (FRL). ${ }^{2}$ I collected the FRL data from the National Center of Education Statistics 2011-2012 Common Core of Data.

I include one school in the sample in which the majority of the student body is eligible for FRL and describe this school as serving a less advantaged student body. At two of the schools, close to half of the student body is eligible for FRL; these schools serve a mixed-advantage student body (see school characteristics in Table 1). Finally, at one school only a small proportion of the study body is eligible for FRL and I describe this school as serving a more advantaged student body. NCES describes all sample schools' level of urbanicity as "large suburb" or "city."

${ }^{2}$ California schools, including those in the study, participate in the National School Lunch Program (NSLP). According to NSLP regulations, FRL eligibility is determined in one or two ways: i) Families have the opportunity to self-report their eligibility using the Household Eligibility Application and ii) through the Direct Certification method, in which the California State Board of Education reports to school districts all children who are part of families eligible for food stamps and/or the Temporary Assistance for Needy Families program and these children are eligible for the lunch program (U.S. Department of Agriculture, 2012). 
$<<$ Insert Table 1 here $>>$

California state law established the Academic Performance Index (API) in 1999 as part of the state's K-12 public school accountability system. The API is a number on a scale of 200 to 1000 that summarizes schools' and districts' group-level student performance based on statewide assessments in multiple content areas. The state API target is 800 . Schools that do not meet that target must meet annual growth targets leading toward 800. I use the 2012 Base measure of API for each sample school, which is calculated based on Spring 2012 testing and was released in May 2013. (California Department of Education, undated[a]) Each school's API from the CA Department of Education 2012 API school level reports Base API (California Department of Education, undated[b]). In the sample schools there is an inverse relationship between the average level of advantage of the student body and school-level academic performance.

The sample schools vary in the number of years they have been authorized as IB World Schools to offer the DP, though only School 3 has offered the IB DP for less than five years while the other three have been authorized for at least 15 years. All of the schools offer the IB DP in addition to Advanced Placement (AP) and College Prep (CP) courses. In one of the schools, teachers teach IB courses - with the exception of TOK and CAS - in combination with AP courses. In all sample schools, IB students comprise a minority of the overall high school population and the majority of IB students participate in the IB DP as diploma candidates rather "IB course takers" who take IB courses in an ad-hoc fashion.

The IBO sent an initial letter of introduction to the selected schools that expressed its support for the study. A follow-up letter explained the project details, highlighted schools' and participants' rights as research subjects, and requested a phone conversation with the IB Coordinator.

The IB Coordinators selected IB teachers and students to participate in the study. It was requested that selected teachers collectively teach CAS, TOK, History of the Americas and English. Across schools, within the IB DP, IB teachers typically take on various roles. For example, a teacher might serve as Coordinator and teacher History courses or teach science courses and TOK or teach English courses and direct the CAS program. In most schools, there was only a limited choice of teaching staff who would logically participate in the study.

A total of 15 teachers participated in the study, three per school at Schools 1, 3 and 4 and six at School 3. Most teachers held multiple roles, including: IB Coordinator $(n=4)$, CAS Coordinator $(n=4)$, English teacher $(n=4)$, TOK teacher $(n=4)$, History of the Americas teacher $(\mathrm{n}=1)$, EE advisor $(\mathrm{n}=2)$ and IB chemistry or biology teacher $(\mathrm{n}=3)$. With just one exception, all teachers in the sample also have current or recent non-IB 
teaching responsibilities. Without exception, no sample teachers have experience teaching IB outside of their current school.

IB Coordinators were asked to select students who represent a range of levels of success and effort. A total of 24 students participated in the study, five at Schools 2 and 4, six at School 1 and eight at School 3. I provide more detail about the student sample below.

\section{Measures}

The data collection instruments include semi-structured interview protocols for students and teachers and a student survey. Interview protocols and survey items were pilot-tested on two teachers and two students and revised accordingly based on their responses.

\section{Student interview protocol}

A challenge inherent to asking people direct questions about citizenship is that the idea of citizenship means different things to different people. To surmount this challenge, the protocol first briefly talked through the idea that citizenship means different things to different people. For example, some people equate citizenship with voting, others with recycling, others with following laws and rules, others with fighting for individual rights and others with issues of legal documentation. Then, in order to avoid the need to explicitly provide a singular definition of citizenship, the protocol followed Westheimer and Kahne (2004, p. 247) by, "asking participants to identify and discuss particular social issues that are important to them... encouraging them to describe their perspective on the nature of the problems, the causes and possible ways of responding... [and] to describe ways in which their participation in [the IB Diploma Programme] might have altered their attitudes, knowledge or skills in relation to those issues". It first asked students to

think about a problem that is important to them, possible ways to address the problem and the knowledge, skills and attitudes necessary to address the problem. Then it asked a series of questions about the extent to which students feel that they develop the "necessary" knowledge, skills and attitudes through the IB DP and through what means, including curriculum, pedagogy, classroom and climate. It also asks students to compare DP versus non-DP course development of their "necessary" knowledge, skills and attitudes. It asks students to provide examples that substantiate all of their responses. See the semi-structured student interview protocol in Appendix A.

\section{Teacher interview protocol}

The semi-structured teacher interview protocol first asks about the DP and non-DP courses teachers teach and then the socio-economic status and academic background of 
the majority of their DP as compared to non-DP students. Then, following Westheimer \& Kahne (2004) it poses questions roughly equivalent to those included in the student protocol. As with the student protocol, the teacher protocol does not define citizenship because the idea means different things to different people. The teacher protocol asks teachers to think about a social issue that is important to their students, the knowledge, skills and attitudes necessary to address that issue and the curricular, pedagogical and climate-based means through which the DP attempts to develop that knowledge, skills and attitudes. The teacher protocol also asks about barriers to developing these "necessary" knowledge, skills and attitudes. See the teacher interview protocol in Appendix B.

\section{Student survey}

I administered the online, 15 minute survey to students individually immediately after conducting each interview.

The survey includes six categories of items that address students':

- Civic skills: Familiarity with effective advocacy techniques

- Civic knowledge: of US government and public policy

- Citizenship orientation: Participatory, personally responsible and social justice orientations

- Civic education exposure: experience with high-quality civic-education practices

- Means: Estimation of the means through which students developed the knowledge, skills and attitudes addressed in the survey

- Background: Demographics and education background

With the exception of the "means" category, the survey only includes items that have been administered as part of other surveys to fairly large populations of high schoolenrolled 17 and 18 year olds. Other researchers have demonstrated the internal consistency of these items with large student samples. The student survey is provided in Appendix C. Further information about survey measurement of each construct, including sources, item lists and internal consistency is provided in Appendix D.

Civic Skills: Familiarity with effective advocacy techniques

To measure students' familiarity with "effective advocacy techniques," a part of the IBO project's definition of "academic civic mindedness," I use a scale administered as part of the California Survey of Civic Education (Kahne, Middaugh \& Coddy, 2005). This measure asks students how well they think they would be able to execute a series of eight civic skills in response to a concrete problem in their community (all survey items in Table 2). 
$<<$ Insert Table 2 here $>>$

\section{Civic Knowledge}

The choice of items to include as measures of students' "knowledge of U.S. government and public policy"- the other part of the IBO's "academic civic mindedness" construct - is challenging. There is no widespread agreement on what exactly the construct of "civic knowledge" should encompass. Knowledge domains, for example, might include what students should be expected to know given their IB DP coursework or what U.S. twelfth graders should expected to know after successful completion of a U.S. Government course. Given time limitations, the survey prioritizes the possibility of comparing the sample IB students' responses to those of other student populations on particular knowledge items over trying to fully capture a knowledge domain.

The knowledge items included in the survey are from two sources, the Center for Information and Research on Civic Learning and Engagement (CIRCLE)'s 2012 youth voting survey and the National Assessment of Education Progress (NAEP) 2010 twelfth grade civics assessment.

Citizenship orientation: participatory, personally responsible and social justice

To measure students' "model citizenship" the survey uses three scales that Kahne and co-authors have used to measure students' civic orientations in previous studies (Westheimer \& Kahne, 2004; Kahne, Middaugh \& Coddy, 2005; Kahne \& Sporte, 2008). The online survey used in the present study randomizes the order of the 17 items for each student in an attempt to rule out the possibility that students could guess how the items "should" fit together and answer correspondingly in a socially desirable way.

Civic education exposure

A 2010 NAEP civics item stem is used to measure the types of high quality civic education practices that the Civic Mission of Schools recommends (Gould, 2011). The item asks students how often they engage in discussion of current events, debates, simulations and letter writing in the following contexts: through the IB DP including DPrelated extracurricular activities; through non-IB DP courses and non-IB DP extracurricular activities; informally with IB DP peers; and informally with non-IB DP peers.

Means

The survey asks students to estimate the means through which they developed the knowledge, skills and attitudes they drew from to answer the survey questions. Response possibilities included the IB DP, non-IB DP courses and extracurricular activities and 
non-school sources. Other response options include, "I don't know" or "I don't have the knowledge, skills or attitudes."

\section{Background}

Finally students are asked to report their age, gender, ethnicity, whether either or both parents were born outside of the U.S., and mother's and father's educational attainment. The survey also asks students about their intention to enroll in college next year, frequency of discussion of political issues with their parent(s), approximate grade point average (GPA), and whether they previously enrolled in IB Primary Years and/or Middle Years Programmes.

\section{Analytic methods}

\section{Qualitative analysis}

All interviews were conducted in English. Parents of students under 18 years of age provided consent for their child to participate in the study. Interviews with teachers and students took approximately 30 and 20 minutes each, respectively. Participants were asked and gave permission to record the interviews.

Notes and audio files were used to create detailed summaries of each interview, following the template strategy approach to facilitate comparability across case study sites (Marshall \& Rossman, 2006). The templates are based on the interview protocols and enable organization of the information into individual summaries. The analysis yielded 39 summary documents, including 24 student interview summaries and 15 IB DP teacher summaries.

Next, summaries were transferred into a single Excel file to organize the qualitative data from all four schools and to further organize the data into more detailed categories. Example categories include, "skills needed," "skills IB DP provides," "student issues of interest," "IB versus non-IB," "Teacher experience," and "Barriers for teachers."

Finally, the information was summarized into analytic memos on each of the interview protocol topics and on cross-topic themes. These memos served as the basis for the presented results I present.

\section{Quantitative analysis}

The small sample size of 24 students in four schools constrained the range of analytic possibilities. Quantitative results for the survey are purely descriptive and are provided only across schools because school-specific sample sizes are too small to make betweenschool comparisons. 


\section{Limitations}

There are several limitations to the validity of the results presented in this paper. The first internal validity threat is that all results are contingent upon students' decision to enroll in the IB DP. Unlike an experimental evaluation of the IB DP "treatment," students were not randomly assigned to the IB DP. Students who choose to enroll in the IB DP likely differ from those who do not in important measured and unmeasured ways. Therefore all findings are contingent not only on the IB DP itself, but on the composition of the students who enroll. The second internal validity threat is that all interview and survey data are reported from the perspective of individual teachers and students so are subject to the limitations of self-report data. The third internal validity threat is that in qualitative research, the researchers' presence affects their participants' behaviors and responses. This concern could be even stronger when interviewing teenagers, because of perceived age and power differences (Marshall \& Rossman, 2006). Though all research subjects gave informed consent, it is possible that they modified their answers to our research questions and/or would have answered differently in a non-research setting.

There are three external validity threats. First, findings from the four sample schools are not representative of all Californian schools that offer the IB DP. Second, selection of IB teachers and students was necessarily left to the IB coordinators and school directors, which could bias the results. Third, the very small sample, both in terms of number of sites and respondents, considerably limits the generalizability of the findings.

The small student sample size $(\mathrm{n}=24)$ poses further limitations to the types of analyses that are possible.

A final limitation is that the survey did not measure knowledge of public policy because of the decision to only include in the survey items that have been administered as part of other surveys to similarly aged samples of twelfth grade students with available validity and reliability information. Assessing knowledge of current public policy is typically time sensitive, so is infrequently measured in such surveys (Niemi, 2012). 



\section{Results}

\section{$R Q$ \#1: Description of the student sample and differences between IB and non-IB students within schools}

Though the student sample is too small to use the background statistics to inform the quantitative analysis, survey responses provide a description of the student sample. All students in the sample are in twelfth grade and data collection took place in January, by virtue of which most are seventeen or eighteen years old. The survey asks about age to confirm that most are in fact seventeen or eighteen so that comparisons to the California Civic Survey, CIRCLE and NAEP samples will be age-appropriate. The average age of students in the sample is 17.3 years (see Table 3 ).

$$
<<\text { Insert Table } 3 \text { here }>>
$$

Gender differences in political participation have been persistent, especially regarding more formal forms of political participation (Hooghe \& Stolle, 2004). Girls compose just over 60 percent of the sample.

Student ethnicity, parental birthplace and parental education - which serves as an imperfect proxy for individual students' socio-economic status - are important because of the civic engagement gap between minority, immigrant and economically disadvantaged students on the one hand, and white, native born and SES-advantaged students on the other (Levinson, 2012b). Overall, over 80 percent of the sample IB students are minority $(n=22)$, with 44 percent of students identifying as Asian, 26 percent Hispanic and 7 percent African American/Black. For 20 percent $(n=5)$ of students both parents were U.S.-born and for 75 percent one or both parents were born outside the U.S.

Two-thirds $(n=10)$ of teachers think that within their school, IB and non-IB students' SES is comparable (see Table 4). These teacher perceptions suggest that across the sample schools the IB DP program is accessible to students regardless of SES.

$$
<<\text { Insert Table } 4 \text { here }>>
$$

Student survey responses about their parents' educational attainment indicate that for the majority, either or both parents have at least some college education (responses for mother's and father's educational attainment are highly correlated). According to students, nearly 80 percent of IB students' mothers have attained at least some college education and only 11 percent had not graduated from high school. As an imperfect 
proxy for family SES, these responses indicate that on average in the sample, IB students are not from impoverished family backgrounds.

The survey asks about students' grade point average (GPA) and college intentions because there is a strong relationship between educational attainment and civic participation (Kahne \& Middaugh, 2008; Nie, Junn \& Stehlik-Barry, 1996). Students included in the survey sample, on average, reported a GPA of over 4.0, indicating strong overall academic performance. The vast majority of students intend to attend a 4-year college (96 percent) with just one student unsure (see Table 5).

$<<$ Insert Table 5 here $>>$

Over two-thirds of the teachers $(n=12)$ indicated that IB students tend to have stronger academic backgrounds than their non-IB counterparts. Since IB is known for its rigorous requirements, this strength of IB students' academic backgrounds is most likely attributable to selection bias.

The student survey asks about frequency of conversations with parents about political issues because of the documented relationship between these conversations and civic outcomes (i.e. Sporte \& Kahne, 2008; Torney-Purta, Amadeo, et al, 2007). Sporte \& Kahne (2008), for example, find in the Chicago Public Schools context that discussion of current events and politics with parents is strongly related to commitment to civic participation as measured with the same Westheimer and Kahne scale used in this study. Close to half of the IB sample discusses political issues with his/her family at least once a week, though 20 percent report only occasional discussion and 20 percent report never discussing political issues with parents.

Finally, of those with official IB preparation, five students - all from the same school-previously participated in the Middle Years Programme (MYP) only and just one participated in both the Primary Years Programme and MYP. Three students participated in a non-MYP $9^{\text {th }}$ and $10^{\text {th }}$ grade IB DP preparatory program.

\section{RQ \#2: IB DP development of students' academic civic mindedness}

Following the IBO's project description (IBO 2013, p. 1), "academic civic mindedness" includes, "student knowledge of the U.S. system of government, public policy and effective advocacy techniques."

\section{Knowledge of U.S. government}

Students' and teachers' interview responses indicate that the IB DP curriculum does not strongly emphasize development of students' knowledge specific to the U.S. system of government. A minority of teachers and students were able to articulate the knowledge 
necessary to understand government functioning, however, they did not provide specific examples of how the DP curriculum develops this knowledge.

In response to interview questions about the knowledge students need to actively address a broad spectrum of political and social issues, five teachers and six students say they need to understand the legal context and how government works. Two teachers further commented that students should understand the balance of power between federal and state levels and between citizens and the government. No interviewees, however, described the curriculum or pedagogy of any DP courses as placing a specific emphasis on building their direct knowledge of how the U.S. system of government works. A history teacher explained that since knowledge of how the U.S. government works is typically not assessed in the Diploma exams, he does not focus on it, though he has found that when he does dedicate a day or two to discussing the U.S. system of government, his students are very interested.

Though the interview results indicate that the DP curriculum does not directly emphasize factual knowledge of U.S. government functioning, several teachers and students pointed out that students have the opportunity to research topics that interest them for their TOK presentations, EE and CAS projects.

\section{Knowledge of U.S. public policy}

All teachers and students $(n=39)$ provided examples of ways in which IB DP curriculum and pedagogy promotes knowledge of U.S. public policy issues. In total students and teachers mentioned 28 separate public policy issues. The most frequently mentioned issues included education quality and equality $(n=7)$, gay rights $(n=5)$ and immigration reform $(n=5)$.

Interview data indicate that the top three IB DP courses through which students develop knowledge of U.S. public policy are TOK, History of the Americas and English. Across schools, seven teachers and 23 students reported that TOK teachers focus on developing students' ability to consider multiple perspectives on a topic through discussion of U.S. public policy issues. A total of 14 interviewees responded that students develop knowledge of public policy issues in the History of the Americas course through, as two students described, "studying topics with social and historical relevance" and "learning how past issues were resolved, which is helpful for implementing change." The same number responded that students learn about public policy issues through study of literature in IB English courses. One English teacher described teaching the social justice ideas of marginalization and universal human rights through literature about apartheid. Another English teacher shared the example of teaching about racism and discrimination through Toni Morrison's Beloved.

Students did not mention foreign languages as a dominant means through which they learn about public policy issues, except for one school where interviewed students 
mentioned their Spanish class as among their most policy-relevant IB courses. Students and teachers across the four schools also mentioned that IB students' knowledge of public policy relevant to their EEs or CAS projects is student-driven $(n=8)$. Finally, three students and two teachers provided examples of addressing public policy issues in mathematics or science courses, for example, the health- and social-implications of the use and sale of marijuana.

\section{Understanding of effective advocacy techniques}

The interview data suggest that the DP strongly promotes students' understanding of effective advocacy techniques through development of the skills necessary to execute advocacy activities.

In response to the interview question on the skills students need to address the social and political issues they care about, across students and teachers the most common responses included: oral communication ( $\mathrm{n}=29$ mentions); interpersonal skills including listening, patience, flexibility, intercultural sensitivity, diplomacy and ability to compromise and negotiate $(n=24)$; written communication $(n=23)$; collaboration or teamwork $(n=10)$; ability to organize activities, information and time $(n=10)$; leadership $(n=8)$; persuasion $(n=8)$; thinking skills including critical thinking, creativity, intellectual humility and respectful questioning $(\mathrm{n}=8)$; research skills including close reading and source evaluation $(n=7)$ and consideration of alternative perspectives $(n=5)$. A teacher summarized these skills as, "the $21^{\text {st }}$ century skills we are struggling to teach all students." Indeed, this list of skills overlaps to a significant extent with most lists of " $21^{\text {st }}$ century skills" that students need for success in college and careers (i.e. AT21CS, undated; Saavedra \& Opfer, 2012; Wagner, 2008). These responses indicate that students and teachers believe that successful implementation of civic advocacy activities requires " $21{ }^{\text {st }}$ century skills" competence.

\section{DP development of students' advocacy skills}

According to all student and teacher interviews (100\%), the DP's heavy pedagogical reliance on discussions, debates, oral presentations, written assignments and teamwork, enables students to develop many of the skills necessary for civic engagement. Teachers commented as follows:

"IB compels students to consider other ways of thinking and articulate in written and oral form. Internal and external assessments promote communication skills. Close reading, understanding of tone and understanding authors' backgrounds are critical to being an informed citizen."

"Discussions and debates help to develop communication and presentation skills, which also develops open-mindedness and general involvement," 
"Presentations and discussions develop effective communication skills, collaboration."

Students expressed similar sentiments about the relationship between IB pedagogy and skill development. Their comments include the following:

"IB has debates, discussions, simulations, which help students feed off of others' ideas, creating better awareness and more skills."

"Through oral presentations, group projects, study groups develop interpersonal and communication skills that we don't develop through lectures."

"Through IB I learned to lead group projects, share opinions, consider others' perspectives and express views without offending others."

Interviewees most frequently mentioned TOK ( $\mathrm{n}=21)$, IB English $(\mathrm{n}=17)$ and CAS $(\mathrm{n}=18)$ contributions to developing students' communication, interpersonal, perspectivetaking and thinking skills. Regarding TOK and English, students explain that,

"My TOK presentation built perspective-taking, public speaking skills, speaking accurately. English oral commentaries build verbal and analytic skills."

"TOK develops leadership skills and interpersonal relations, other IB classes do too."

Regarding other IB DP courses' development of skills necessary for civic engagement, five interviewees each mentioned History and the Extended Essay, and three mentioned additional language courses. Only two interviewees (one teacher and one student) mentioned IB mathematics or sciences courses as opportunities to develop civic skills.

\section{CAS development of students' civic skills}

The IBO defines Creativity to include, "arts and other experiences that involve creative thinking," Action to include, "physical exertion contributing to a healthy lifestyle," and Service as, "an unpaid and voluntary exchange that has a learning benefit for the student (IBO, 2008b, p.11). Students must successfully fulfill their CAS requirements to earn the Diploma - successful completion is determined through students' documentation of their activities and demonstration of engagement with eight specified learning outcomes.

Students can develop the skills necessary for civic engagement through CAS, though the extent to which they do seems to depend on both the way the school organizes the CAS program and individual students' level of motivation. In the best-case scenario, exemplified at one sample school, students' CAS experience is a mission-based project 
through which students actively address a social topic about which they are passionate about effecting change. They start with an issue they may have learned about through TOK or other DP course discussions. They develop and execute a comprehensive project plan, beginning with a mission statement, including plans for time management, resource management and expected outcomes and follow through to a major culminating goal. This version of the CAS experience is explicitly not about counting hours, and students' meetings with their CAS coordinators are outcomes focused, not time focused.

At this school, all the teachers and all but one student reported that CAS develops useful skills. Within the careful structure of the best-case scenario CAS, most students seem to find a project they care about and develop valuable project management skills that will serve them well as citizens and in their careers. Students at the best-case scenario school described starting a club to promote recognition of the rights of intellectually disabled students, engaged in a project to beautify an elementary school, started a peer-counseling program and advocated for animal rights culminating with an animal adoption event. For each project, according to student interviews, they started with an issue they were passionate about (educational improvement, student emotional struggles, animal rights), created a detailed work-plan including goals and action steps to reach those goals, communicated their ideas to adults and peers from whom they needed support (including elementary school and high school principals and shelter staff), collaborated with others, persisted through setbacks, reflected on their personal growth, executed a culminating event and earned the satisfaction of reaching their goals.

In comparison, at the three other schools, a small minority of interviewees described CAS as a means through which students develop the skills necessary for civic engagement (one student and one teacher each at two schools and three students but no teachers at another). In the worst-case scenario, students and teachers see CAS solely through the lens of counting hours, such that according to a teacher, a student would "count" the hours he/she already spent on the soccer team to fulfill the CAS commitment.

Except for the school with well-structured CAS program, student comments about CAS were mixed and indicated that, "CAS can be meaningful if you are passionate about the activity and getting something out of the experience. If you are not, it's about logging hours." Without a strong CAS structure and self-motivation, students could fail to engage with their CAS project and correspondingly not develop useful skills. That said, even when the CAS structure promotes hour counting as the chief outcome, some students with strong self-motivation positively harness their experience. For example, three students in the program their teacher described as "hour-counting" explained the value they had gained through CAS including, "Thinking about the learning outcomes," "Learning the perspectives of others in the community," and "Being forced to volunteer." 


\section{Student experience with civic education "best practices" through the IB DP}

Student survey responses quantify the extent to which they feel they engage through the IB DP in the sorts of educational activities that develop the skills necessary for civic engagement (Gould, 2011). Close to 100 percent reported that they discuss current events at least once a week through the DP, 60 percent of which do so daily (see Table 6). The majority ( 70 percent) of students also report that they debate in the DP at least weekly and that simulations, though occurring at somewhat less frequency, take place at least once a month. Only letter writing takes place in the IB DP with notably less frequency, with a quarter of the IB students indicating that they do so just a few times a year and 45 percent indicating they never write letters. ${ }^{3}$ The respective frequencies of IB students' discussion of current events, debating and simulations formally through the DP are similar to those that students report they engage in informally with their DP peers.

$<<$ Insert Table 6 here $>>$

Students report engaging in discussion of current events, debates, simulations and letter writing with much less frequency during non-IB courses and extracurricular activities and with their non-DP peers. For example, only 25 percent of students reported discussing current events at least weekly in their non-IB courses and the majority rarely or never debate or engage in simulations in their non-IB courses or with their non-IB peers. The infrequency of civic education best practices in non-IB courses and extracurricular activities, for the most part, mirrors the national trend with the exception of current events - approximately 60 percent of the national sample reports classroom discussion of current events at least weekly.

\section{RQ \#3: IB DP students' academic civic mindedness performance}

The student survey measured students' knowledge of U.S. government using four CIRCLE and six NAEP items. The survey also measured students' comfort implementing eight advocacy techniques and where students believe they developed most of the knowledge, skills and attitudes measured in the survey.

Compared to the nationally representative CIRCLE and NAEP samples, higher proportions of students in the IB sample answered nine of the ten questions correctly. At least three-quarters of the IB students reported that they "probably can" or "definitely can" implement each of the eight advocacy activities. Finally, two-thirds of students estimate that they learned most of the knowledge tested in the survey through the IB DP.

${ }^{3}$ A possible explanation for the infrequent letter-writing responses may be semantic. While the survey maintained the item language to ensure comparability with NAEP, students may not have considered letters to include those sent through email. 
Nearly half estimate that they gained the skills necessary to implement the eight advocacy activities through the IB DP.

\section{Knowledge of U.S. government}

Compared to the CIRCLE national sample of high school enrolled or recently graduated 18 year olds, the proportion of IB students scoring correctly on each of the four CIRCLE items was greater by approximately twenty percentage points. Across the four items, on average 74 percent of IB students scored correctly compared to just 51 of CIRCLE students (see Table 7).

$<<$ Insert Table 7 here $>>$

The proportion of IB students scoring correctly on each of the NAEP items (56 percent) is also higher than the national population (45 percent). The only exception is in response to the question that asks how the federal system encourages the growth of organized interest groups, to which 50 and 55 per cent of the IB and NAEP samples responded correctly.

Regarding IB students' absolute performance on the knowledge items, in response to five of the six items, approximately half of the IB student sample answered correctly. The majority ( 83 percent) of IB students responded correctly to just one item, which asked about the historical circumstances that facilitated the passage of the Fourteenth Amendment.

\section{Comfort implementing effective advocacy techniques}

The vast majority of students indicated that they probably or definitely can accomplish each of the eight advocacy activities (see Table 8). Over half of the students responded that they definitely can "express views in front of a group of people," and "Call someone on the phone that you have never met before to get their help solving the problem." The only activities that more than four students think they "probably cannot" execute are "contacting an elected official about the problem" and "organizing a petition"- and even with those, no students said that they "definitely cannot."

$$
<<\text { Insert Table } 8 \text { here }>>
$$

\section{IB DP contribution to students' academic civic mindedness}

In response to the student survey question that asks, "Please describe how you gained most of the knowledge addressed in this survey," close to 70 per cent $(n=16)$ of students responded, "through the IB DP including DP-related extracurricular activities (see Table 9). Since the CIRCLE and NAEP knowledge items ask exclusively about U.S. 
government (as opposed to addressing public policy issues), we can understand students' responses to this survey question to mean that most students feel they have gained some knowledge of U.S. government through the IB DP.

\section{$<<$ Insert Table 9 here $>>$}

In response to the survey question that asks how IB develops the skills necessary to engage civically, 11 of the students reported that they gained most of the advocacy skills through the IB DP, eight through non-IB DP courses or extracurricular activities, three from non-school activities and five said they don't know how they acquired their skills. These responses seem lower than expected given students' interview responses about the skills they believe they are acquiring through their IB DP participation and their surveyexpressed perceptions of the high frequency of the IB DP's civic education best practices implementation. A possible explanation is that students gain comfort with advocacy skills through their participation in clubs and other extracurricular activities that they do not consider DP activities, even if their involvement is technically part of their CAS requirement.

\section{RQ \#4: IB DP development of students' model citizenship}

This study follows the Westheimer \& Kahne (2004) participation, personally responsible and social-justice citizen typology as a means of conceptualizing "model citizenship."

The interview and survey data suggest that individual teachers and students relate to several citizenship types simultaneously. Teachers seem to most frequently identify with participatory, followed by social justice and then personally responsible citizenship. Student survey and interview results indicate that they most strongly relate to the social justice type, followed by personal responsibility and then participatory citizenship. According to the student and teacher interviews, the IB DP develops students' model citizenship through promoting their awareness of political and social issues, required active engagement with a community issue and, to some extent, development of the attitudes students deem necessary for civic engagement.

\section{Teachers' conceptions of model citizenship}

A teacher's personal civic orientation - and the strength of their conviction - can affect the type of "model citizenship" they consciously or sub-consciously promote through their teaching (i.e. Barton, 2012). As one teacher explained, the quality and frequency of teachers' citizenship-related teaching, "often relates to teachers backgrounds and their own values, morals and sense of civic mindedness. If they aren't present, 
citizenship isn't part of the teaching."

Two-thirds $(\mathrm{n}=10)$ of the teachers said that they frequently and consciously attempt to promote students' awareness of local, state, national and/or international issues-a critical feature of the participatory citizen — through their curriculum and pedagogy, particularly through discussion of current events. All four TOK teachers attempt to develop students' concern with political and social issues, for example through discussions of newspaper editorials and Op-eds to expose students to multiple perspectives and the idea that people develop divergent opinions from the same set of "facts." All four IB English teachers provided examples of ways they promote discussion of political and social issues including how to share resources, racism and gender discrimination. Two CAS Coordinators' comments also indicated their perspective that CAS is a prominent means through which the IB DP promotes the ideal of the participatory citizen who takes the step beyond awareness to actual civic engagement with issues that affect the local or wider community.

A quarter $(n=6)$ of the teachers' comments suggest that they relate to the social justice conception of citizenship. Three teach at one of the sample schools and the other three teach across two other sample schools. At the school with the concentration of socialjustice oriented teachers, the DP Coordinator explained that,

"Their pre-IB summer reading assignment addresses social issues. Last summer students read a book that addressed race relations, poverty, public health and education, themes they discussed during the first weeks of IB. I impose a social justice issue on the program, inequality of educational opportunities in Los Angeles."

At another school, an English teacher's interview responses emphasized the DP "Power and Privilege" unit that encourages teachers to address differences between marginalized and mainstream populations' rights in the U.S. and in other countries, and a biology teacher addresses the issues of equity of access to medicine and the social implications of AIDS, particularly for areas in Africa where the disease has had the most devastating effects. At a third school, the TOK teacher explains that, "IB promotes social justice and political engagement... [though] it doesn't happen institutionally or systematically, rather happens on a teacher-to-teacher basis."

A smaller proportion of teachers' comments reflected a strong orientation to the personally responsible conception of citizenship. A comment representative of the four sample IB DP teachers who relate to the personally responsible conception, at least as part of their conceptualization of model citizenship is, "For all students I should be teaching subject matter and how to be a good person and community member. You can't prepare for college and career without also preparing for citizenship."

Finally, at least to some extent, two teachers seemed to equate citizenship with 
patriotism. One said that, "instead of developing citizenship through activities like mandated Pledging Allegiance to the Flag, public schools should develop good thinkers who question and doubt." The other strongly critiqued the "anti-IB" idea that learning about global issues and developing concern for others beyond national borders interferes with students' citizenship development.

Another way to assess the extent to which teachers identify with and strive to promote participatory, personally responsible and/or social-justice oriented citizen types in their IB DP students is to analyze the attitudes they believe students need to advocate on behalf of political and social issues. Across schools, teachers responded that the most important attitudes students need are empathy $(\mathrm{n}=6)$, confidence $(\mathrm{n}=5)$, motivation $(\mathrm{n}=4)$, persistence $(n=3)$, sense of efficacy $(n=3)$, openmindedness $(n=2)$ and optimism $(n=2)$. One teacher each also spoke of the importance of humility, tolerance and sense of community. Empathy might relate most strongly to personal responsibility or social justice. Openmindedness might also relate most strongly to social justice. The other attitudes arguably apply equally to the three Westheimer and Kahne citizen types.

\section{Student conceptions of model citizenship}

Student survey responses indicate that they most strongly identify with a social justice citizen orientation, such that 84 percent of students strongly agree or agree with statements that describe the social justice orientation, 49 percent of which strongly agree (see Table 10). In comparison, 70 percent of students strongly agree or agree with the personal responsibility statements ( 38 percent strongly) and 65 percent with the participatory statements (29 percent strongly). This is not to say that in the absolute, sample students do not relate to participatory citizenship. On the contrary, in response to the "participation item" that asks students to rate their agreement with the statement, "Being actively involved in state and local issues is my responsibility," only 8 percent of the IB sample disagrees, compared to 53 percent of Californian twelfth graders who responded to the California Civic Survey (Kahne, Middaugh \& Croddy, 2005, p. 2). ${ }^{4}$ Thus, while IB students in this study relate most strongly to the social justice orientation, they also demonstrate strong agreement with the personally responsible and participatory orientations.

$<<$ Insert Table 10 here $>>$

In agreement with the survey results, in response to the interview question asking students to think of a social issue they were concerned about, most students responded with a problem related to social justice. As Westheimer and Kahne (2004, p. 247) note,

${ }^{4}$ Both samples responded to the same item. 
whether students, "emphasize needs for individual morality, civic participation or challenges to structures or social inequalities" sheds light on their citizenship orientation. Students could have posed problems that indicated identification with participatory or personally responsible citizenship and that according to teacher interviews they had studied in the IB DP-like the Ukraine-Russia political situation, social media regulations or gun control - though none did. The clear majority of students $(n=20)$ chose as their example an issue that indicated concern for social inequalities. Topics included: world hunger; distribution of wealth and consequential poverty; inequitable education access and quality; disability students' rights; bullying; immigration reform; gay rights; media disenfranchisement and misrepresentation; tolerance of other cultures and religions; and racial and sexual discrimination. The only topics that students $(n=4)$ presented that seem less directly related to social inequalities (e.g., animal rights, the 2014 California water shortage and other environmental concerns).

This interview comments illustrates students' social justice orientation: "Through philosophical discussions of justice in TOK and IB Philosophy, students develop their own definitions of citizenship." Regarding the participatory orientation, most IB students feel that they are more informed about social issues through IB than they would be otherwise and that being informed makes them want to be involved. Representative student comments include,

"I wouldn’t know about many social issues without IB."

"Learning about social issues makes me want to try to address them. I didn't care about what was going on in the world before IB. IB makes you think outside of the book. I wouldn't be as involved if not for IB."

Three students' comments indicated identification with personally responsible citizenship, for example, "IB promotes the ethics of social issues. Teachers try to develop character, not just intellectual capacity."

\section{$\underline{\text { Range of student perceptions of IB development of model citizenship }}$}

Students' comments about the extent to which they feel that IB develops model citizenship fall on a continuum ranging from the belief that IB does nothing and students' civic engagement is entirely self-driven to IB definitely promotes students' citizenship. Though not every student provided an explicit comment on the extent to which the DP promotes citizenship, the perspectives of those that did fall into three categories. On one side of the continuum, four students believe that the DP does not develop students' citizenship. Comments included, "IB doesn't explicitly develop any of the necessary skills, knowledge and attitudes, its all about what the individual student brings." 
In the middle are two students who felt that students' model citizenship development results from an interaction between the individual student's level of motivation and the IB DP, such that "Civic ideals in IB are holistic and high-level, however, they sink in, in part due to students' personalities."

Finally ten students feel that the IB DP promotes citizenship. Representative comments include,

"IB helps students to be more civic human beings because it asks what we think rather than just open the book and take notes."

"IB is about being globally aware and encouraging civic engagement."

\section{Cross-model attitudes necessary for civic engagement}

Analysis of the attitudes students believe are necessary to advocate on behalf of political and social issues shows objectivity $(n=8)$ at the top of the list, followed by motivation $(n=7)$, optimism $(n=6)$, openmindedness $(n=5)$, persistence $(n=5)$, sense of efficacy $(n=3)$, empathy $(n=2)$, confidence $(n=2)$, and ability to compromise $(n=2)$. One student each mentioned the importance of humility and tolerance. These attitudes do not seem to relate more strongly to one citizen orientation above another. However, they suggest a closer look at the DP structural features that might develop students' most frequently mentioned "necessary" civic attitudes.

The ingrained cross-DP emphasis on seeking and understanding multiple perspectives may affect students' valuing of objectivity, openmindedness and ability to compromise. Descriptive student comments include, "Exposure to issues where you have to analyze and take a perspective helps to be openminded,"

IB DP structural features that develop students' motivation include the choice to study and engage in areas and projects of personal interest to them through EE, the TOK project and CAS. As a student explained,

"The choice to address a topic you really care about builds motivation, as does coping with stress and completing an enormous project. I have always been a motivated person but IB develops it further."

Other students explain that learning through non-textbook sources motivates students because, for example,

"In IB you pull from previously discussed ideas, knowledge is not static, this is very motivating."

For another student, motivation stems from feeling attention from her teachers,

"IB teachers pay attention to students, this builds motivation." 
Many students explained that the volume and rigor of the DP requirements as well as the opportunities they provide help to develop their persistence, sense of efficacy and confidence. Illustrative comments included,

"IB helps you feel that you can accomplish things, for example, past IB students say IB helped them prepare for college, instilling confidence."

"It was rewarding to see how we could effect change through CAS, at the same time building optimism and trust among our team members."

Though it is valuable to understand the attitudes students believe are necessary for civic engagement and ways in which the IB DP develops those attitudes, in response to the survey question that asks how they gained most of the attitudes addressed in the survey, only six students responded "through the IB DP including DP-related extracurricular activities." Of the other 18 students, five reported "through non-IB DP courses or extracurricular activities," 11 through "non-school sources" and five "don't know."

A possible interpretation of the survey results is that students did not equate the questions intended to measure citizenship orientation with "attitudes." Another possibility for the disconnect between students' interview and survey responses is that the interview question prompts students to give examples of ways in which the IB DP may develop the attitudes students need for civic engagement, which is different from providing an overall rating about the source of attitudes. Regardless, the incongruity between the interview and survey responses leads to the conclusion that the data are inconclusive as to whether and the extent to which the IB DP promotes model citizenship.

\section{$\mathrm{RQ} \# 5$ : IB compared to non-IB alternatives}

Based on their experiences as students in non-IB high-school level courses, the majority of students feel that IB curriculum, pedagogy and climate develop students' academic civic mindedness and model citizenship to a greater extent than do the alternative tracks, which are California College Prep (CP) and Advanced Placement (AP) in the sample schools. An example student explains,

\footnotetext{
'In non-IB, you learn the material, take a test and that's where it ends. In IB it's more of a circle, where you want to create well-rounded individuals, IB focuses on building up the person. IB makes students more concerned about the community."
}

Teachers responded similarly, for example, this quote encapsulates the common sentiment that, 
"Creating critical, thoughtful and reflective people is most important to developing citizens. That doesn't happen in non-IB classes."

In response to the interview question that asked students and teachers to compare IB versus non-IB on development of civic knowledge, skills and attitudes, 31 of 39 respondents' comments indicated that IB places a stronger emphasis on civic development than do the AP and CP alternatives.

Note that at one sample school, all IB courses - with the exception of TOK - are offered as an IB/AP combination course. At that school, two out of five interviewed students reported no difference between IB and AP. Of the other three students at this school, two responded that TOK is the main difference between IB and non-IB alternatives and one responded that teachers are more committed to IB students than to non-IB students. Also from the combined IB/AP school, two of three teachers reported that TOK is the main difference between IB and other options.

Across schools, three teachers indicated that curricular pacing is a primary reason for why they feel it is possible to develop students' citizenship through IB. A representative comment is,

"IB offers more opportunity to build citizenship than AP because you have more time, two years, with the kids - time to build trusting relationships, affect how they behave, build a safe place for talking about things. In AP you are racing against the clock the whole year. You could address citizenship for three weeks after the May exams."

Teacher comments specific to particular aspects of the IB curriculum that promote citizenship more than other programs include,

"By virtue of EE alone, IB engages students more- because many non-IB students graduate from high school without being able to write."

"[The difference is like] night and day-nothing else on campus has CAS, attempting to involve every kid on a community project."

Student observations about the difference between IB and non-IB curriculum address course purpose, instruction, community and teachers. Regarding differences between the purpose of IB versus non-IB courses, students believe that IB courses have a greater social focus than non-IB courses. Purpose-related comments include,

"Non-IB English focuses on technique and literature, not on society. Other non-IB classes focus on standards, not social ideas."

Instruction-related comments include, 
"In AP and CP, students are expected to learn the curriculum, in IB you learn to apply what you learn."

In specific comparison to $\mathrm{AP}$ - a common alternative for IB students given its rigor11 (nine students and two teachers) respondents indicated that IB curriculum and instruction develop thinking, transfer of skills and knowledge and love of learning for its own sake, compared to the AP emphasis on test preparation and "regurgitation," through the lecture, book and test instructional model. Four respondents - two from the school that combines IB and AP and two from another school-explicitly disagreed, stating instead that IB and AP are for the most part comparable.

Most student comments about the difference between IB and AP curriculum and instruction capture the sentiment that the purpose of IB is to learn whereas the purpose of $\mathrm{AP}$ is to pass a test. Student comments indicate unanimous preference for the IB curriculum over AP. For example,

"AP classes are just preparation to take that one test at the end of the year. IB classes are more about learning than about the test."

"AP is just about reading out of the book. In AP Art History and AP European History there is no exposure to social ideas, rather there is something to learn and you have to learn it. In AP if you don't understand something you just move on. In IB you pull from previously discussed ideas."

"In AP it is about transferring information from textbooks to students, if it's not in the textbook it doesn't matter because the test is about the textbook. IB is less book-heavy."

\section{RQ \#6: Barriers to emphasis on civic mindedness and model citizenship}

In response to the teacher interview question about barriers to addressing academic civic mindedness and model citizenship through IB DP curriculum, pedagogy and culture, teachers' mentioned a variety of obstacles. None of these obstacles were cited by a majority of teachers. The top three responses included: 1) teachers' lack of clarity on how to make the content and skills they teach relevant to civic purposes, particularly for mathematics and science teachers $(n=7) ; 2)$ student limitations $(n=4)$ and 3) Diploma examination questions' lack of focus on either construct $(n=3)$. Other barriers mentioned by one or two teachers each included: lack of collaboration between IB teachers and administrators $(n=2)$ and among IB teachers $(n=1)$; logistical red tape $(n=2)$; challenges inherent to attempting to teaching AP and IB curriculum within the same course (only one sample school adopts that strategy), $n=2)$; challenging school climate $(n=1)$; challenging to teach writing $(n=1)$; need for more CAS structure $(n=1)$; and the need for teachers to philosophically support IB's civic focus $(n=1)$. 
The most widely held concern, expressed by seven teachers across two schools, is that they do not know how to frame the skills, knowledge and attitudes they teach as relevant to development of academic civic mindedness and model citizenship - or even, for one teacher-as more broadly relevant to development of the IB Learner Profile qualities. Comments include,

"Beyond CAS there is no organized way to address social issues and citizenship," "We don't receive much support from IB, just the CAS guide."

"IB needs to tighten connection between oral/written communication and citizenship - it would be helpful to have more guidance from IB on that."

One teacher noted that, "it would be clearer to me to know what to do to promote citizenship if there was a specific civic mindedness goal." This teacher did not think that striving to develop the Learner Profile qualities is concrete enough of a goal.

Comments from teachers at one school indicate that connections between the curriculum and citizenship are particularly unclear for mathematics and science teachers. According to a Coordinator, "When you peel back the IB hexagon, the Learner Profile connections are not so clear for math and the hard sciences. I would like more guidance from IB, but they always tell me to read the guide, which I already have read 3-4 times." Another teacher explained, "I don't get guidance from the IB science materials the way I do from the California College Prep 'Chemistry in the Community' curriculum on how to integrate civic ideas into my IB curriculum and pedagogy.”

Four teachers mentioned the second barrier, that IB students are too limited in their basic skills to attempt to also develop their academic civic mindedness and model citizenship. Representative comments include,

"There is too much grind to master the content, which limits the open-ended thinking that takes place."

"It's a huge undertaking for kids to prepare for the Diploma, citizenship takes the back seat."

One teacher from each of three schools explained that the Diploma exam questions do not address academic civic mindedness or model citizenship and this can affect the extent to which they prioritize teaching civic themes. Teachers pointed out that,

"IB English assessments are not designed to demonstrate mastery of social justice, rather of certain literary skills."

"Everything is about the test, we do what we are evaluated on. If IB wanted to add a Diploma Exam 'Topic 6: the Americas and Civics' we'd all be teaching that." 


\section{Findings and Recommendations}

Despite several national initiatives intended to increase U.S. public schools' emphasis on development of students' academic civic mindedness and model citizenship, including work sponsored by the Association of American Colleges and Universities, the American Political Science Association, Justice Sandra Day O'Connor, the U.S. Department of Education, and a number of high-profile foundations, most U.S. schools do not prioritize either objective (i.e.: Campbell, Hess \& Levinson, 2012; Battistoni, 2013). IB programmes are a widely implemented intervention - currently operating in 1,500 U.S. schools, over $90 \%$ of which are public — with a strong stated commitment to developing students' citizenship. Greater understanding of both the extent which the IB DP promotes students' citizenship and the means through which it does so could contribute to strengthening the effort to improve the current state of U.S. civic education. It can also provide the IB Organization with recommendations for how to improve its civic focus. This study takes a first step in that direction. However, given the small sample size and other data limitations, the results and recommendations are suggestive rather than definitive. Further research is needed to fully address how the IB DP can develop civic mindedness and the implications for civic education.

\section{Summary of results}

- According to teachers, students who enroll in the IB DP in the four sample schools have, on average, similar socio-economic backgrounds compared to their non-IB peers within the same school. IB DP students' academic backgrounds are stronger, which is not surprising because only motivated, brighter students are likely to seek to enroll in the DP or be recommended by teachers to do so.

- According to all student and teacher interviews (100\%), the DP's heavy pedagogical reliance on discussions, debates, oral presentations, written assignments and teamwork, enables students to develop many of the skills necessary for civic engagement. For example, the DP emphasis on seeking, considering, weighing and synthesizing different perspectives, particularly through the Theory of Knowledge (TOK) course, seems to develop students' critical thinking, objectivity, openmindedness and ability to compromise, which are skills students and teachers believe are necessary to advocate on behalf of social issues. IB could be more intentional to teachers, and teachers in turn to students, about the civic applications of these skills. 
- The list of skills that students and teachers believe are necessary for civic engagement overlaps to a significant extent with most lists of skills that students need for success in college and careers.

- The IB DP places a strong emphasis on students' knowledge of issues related to public policy, particularly through discussions of current events in TOK, English, History and additional language courses.

- Student and teacher interviews indicated that the IB DP does not seem to strongly prioritize students' knowledge of U.S. government structure and functioning. The student survey results, however, show that compared to nationally representative samples of similarly aged $12^{\text {th }}$-grade students, the sample students scored higher on nine of ten items that tested their knowledge of U.S. government structure, functioning and history.

- Though the data suggests that individual teachers and students relate to several citizenship orientations simultaneously, teachers may most frequently identify with participatory, followed by social justice and then personally responsible citizenship. Students most strongly relate to the social justice orientation, followed by personal responsibility and then participatory citizenship, though in the absolute, students identify quite strongly with all three orientations.

- The IB DP develops students' model citizenship through promoting their awareness of political and social issues and required active engagement with a community issue. Several structural features of the IB DP may also develop the attitudes students deem necessary for civic engagement, including student choice, non-textbook learning, motivated teachers and rigorous requirements.

- In the schools included in the study, alternatives to courses offered through the IB DP primarily include Advanced Placement (AP) and California Prep (CP) courses. Like the IB DP, AP courses also have a rigorous college preparation reputation while the CP courses are not honors level and are intended for students with average or below average academic backgrounds. Most IB students and teachers feel that IB DP develops students' academic civic mindedness and model citizenship to a considerably greater extent.

- Teachers feel that the strongest barrier to prioritizing students' citizenship development is lack of clarity on how to frame the civic implications of the knowledge, skills and attitudes they seek to develop. A few teachers also feel that students' academic deficiencies and lack of Diploma examination questions' emphasis on citizenship also challenge their civic focus. 
Implications for all educators concerned with the civic purposes of education

These results have four tentative implications for the greater community of civic education researchers, practitioners, policy makers and advocates. First, the skills that educators, parents and employers believe are necessary for success in college and career are the same skills that students and teachers believe are necessary for civic engagement. This finding implies that preparing students with the skills they need for college and career and for civic engagement is not a zero sum game. One need not come at the expense of the other. As part of efforts to increase the schools' civic focus, the civic education community might emphasize this message to teachers, including the need to be explicit with their students about the overlap.

Second, with the rollout of the new Common Core State Standards, most educators are struggling to figure out how to teach students to think critically. The DP emphasis on seeking, considering, weighing and synthesizing different perspectives, particularly through the TOK course, develops not only critical thinking, but also students' valuing of objectivity, openmindedness and compromise. These attitudes are valuable in citizens and workers.

Third, the "best-case" CAS model of structured, reflective, required community engagement could be a valuable one for other schools to follow.

Finally, the survey developed to measure sample IB DP students' academic civic mindedness and model citizenship could be used to measure those constructs in other students.

\section{Recommendations for the IB Organization}

The study results also have six implications for the IB Organization (IBO). First, variation in teachers' and students' awareness that the IB DP program can develop academic civic mindedness and model citizenship suggests that IB could be more intentional in illuminating the civic connections for teachers in their curricular and pedagogical materials and through professional development (PD). Greater IBO intentionality could increase emphasis on developing students' academic civic mindedness and model citizenship across IB World schools and reduce cross-school variation.

For example, all teachers should understand that students' development of sophisticated reading, writing and oral communication skills are critical to civic engagement and should know how to effectively share that message to students. This recommendation is particularly salient for mathematics and sciences teachers. Likewise, all students should understand that the ability to see different sides of an argument is critical for effective deliberation. The IBO could also be more explicit about the benefits of student-driven acquisition of knowledge of the U.S. government and legal structure for 
successful EE, CAS and TOK projects. This first implication echoes the Delli Carpini \& Keeter finding that, "Citizens do need to be more engaged in politics, but the reasons for paying attention need to be clearer to them, the benefits of stronger citizenship must be more evident and the opportunities to learn about politics more frequent, timely, and equitable" $(1997,21)$.

Second, IB could be more explicit to teachers that there is a great deal of overlap between the knowledge, skills and attitudes (KSAs) necessary for civic engagement and for college and career preparation so that teachers internalize and again, share that message with students. Once teachers understand the civic relevance of the KSAs students build through IB DP participation and that development of civic capacities is not in conflict with preparation for college and career, they should understand that development of civic-relevant KSAs is not time-consuming. On the contrary, the IB DP model seems motivating and to simultaneously prepare students for "college, career and citizenship" (Levinson, 2012a, 250).

Third, according to three sample teachers, if the IBO wants to increase teachers' and students' focus on development of academic civic mindedness and model citizenship they should consider strengthening teachers' accountability to this purpose through greater Diploma examination focus on this objective.

Fourth, there is considerable variation in CAS implementation across the four sample schools. Only one of the four schools offers the program in a way that seems to truly maximize students' knowledge, skills and attitude development. The IBO could help to improve the CAS program by providing schools with more detailed guidance on the best ways to structure it.

Fifth, though just one teacher raised the issue, teachers' own citizenship orientation and the strength of their belief in the civic purpose of education contributes to the extent to which they are inclined to develop their students' civic mindedness and citizenship (Barton, 2012). In addition to making citizenship connections more explicit through subject-specific materials and PD, the IBO could consider offering PD sessions that focus on guiding teachers to understand their own civic orientations (Hess \& Zola, 2012).

Finally, the survey developed to measure sample IB DP students' academic civic mindedness and model citizenship could be used to measure those constructs in other IB DP students. 



\section{References}

Assessment and Teaching of 21 st-Century Skills. (Undated). What are 21 st-century skills. Retrieved from http://atc21s.org/index.php/about/what-are-21st-century-skills/

Barton, K. (2012). Expanding Preservice Teachers' Images of Self, Students and Democracy. In Campbell, D., Hess, F. \& Levinson, M., Eds. (2012). Making Civics Count: Citizenship Education for a New Generation. Cambridge, MA: Harvard Education Press.

Battistoni, R. (2013). Should Political Scientists Care about Civic Education? Perspectives on Politics 11 (4).

Billig, S.H. and Good B.M. (2013). International Baccalaureate Diploma Programme: Study of North and South American students' civic-mindedness, Phase II. Denver, Colorado: RMC Research Corporation

Brunold-Conesa, C. (2010). International Education: The International Baccalaureate, Montessori and global citizenship. Journal of Research in International Education. 9 (3) 259-272.

Byrd, S., Ellington, L., Gross, P., Jago, C., \& Stern, S. (2007). Advanced Placement and International Baccalaureate: Do they deserve gold stars? Washington, DC: Thomas B. Fordham Institute.

California Department of Education (undated[a]). Retrieved from http://www.cde.ca.gov/ta/ac/ap/documents/apiexecsummary.pdf

California Department of Education (undated[b]). Retrieved from http://api.cde.ca.gov/reports/page2.asp?subject=API\&level=School\&submit1=submit

Campbell, D., Hess, F. \& Levinson, M., Eds. (2012). Making Civics Count: Citizenship Education for a New Generation. Cambridge, MA: Harvard Education Press.

Caspary, K., and J. Bland. 2011. First College Courses Taken by Florida IB Students. Centre for Education Policy, SRI International. http://www.ibo.org/research/policy/programmevalidation/diploma/.

Cech, S. J. (2008). World grows smaller, IB gets BIG. State Legislatures, 34(2), 20-24.

CIRCLE (2013). All Together Now: Collaboration and Innovation for Youth Engagement: The Report of the Commission on Youth Voting and Civic Knowledge Medford, MA: Center for Information \& Research on Civic Learning and 
Engagement. Retrieved from www.civicyouth.org/about-circle/commission-onyouth-voting-civic-knowledge/

Coates, H., C. Rosicka, and M. MacMahon-Ball. 2007. Perceptions of the International Baccalaureate Diploma Program among Australian and New Zealand Universities. Australian Council for Education Research. http://www.ibo.org/research/policy/programmevalidation/diploma/.

Coca, V. D. Johnson, T. Kelley-Kemple, M. Roderick, E. Moeller, N. Williams, and K. Moragne. 2012. Working to my Potential: The Postsecondary Experiences of CPS Students in the International Baccalaureate Diploma Programme. The University of Chicago Consortium on Chicago School Research. http://ccsr.uchicago.edu/publications/working-my-potential-postsecondaryexperiences-cps-students-international-baccalaureate.

Conner, J. O. (2008). From international schools to inner-city schools: The first principles of the International Baccalaureate diploma program. Teachers College Record, 110 (2), 322-351.

Culross, R., and E. Tarver. 2011. "A Summary of Research on the International Baccalaureate Diploma Programme." Journal of Research in International Education $10(3): 231-243$.

Delli Carpini, M. \& Keeter, S. (1996). What Americans Know About Politics and Why It Matters. New Haven, Yale University Press. Education Commission of the States.

Education Commission of the States. (2011). State Policies for Civic Education Database. http://www.ecs.org/ecsmain.asp?page=/html/ProjectsPartners/nclc/nclc_main.htm

Flanagan, C., Syvertson, A. \& Stout, M. (2007). Civic Measurement Models: Tapping Adolescents' Civic Engagement. CIRCLE Working Paper \#55. Medford, MA: The Center for Information and Research on Civic Learning and Engagement.

Gardner, H. (2006). Five Minds for the Future. Boston, MA: Harvard Business School Press.

Gould, J., Ed. (2011). Guardian of Democracy: The Civic Mission of Schools. Philadelphia, PA: Leonnore Annenberg Institute for Civics of the Annenberg Public Policy Center, University of Pennsylvania; Silver Spring, MD: The Campaign for the Civic Mission of Schools. Retrieved from www.civicmissionofschools.org/site/

Gutmann, A. (2000). Why Should Schools Care about Civic Education? In McDonnell, L.M., Timpane, P.M., Benjamin, R. eds. (2000). Rediscovering the Democratic Purposes of Education. Lawrence, Kansas: University Press of Kansas. 
Hess, D. (2009). Controversy in the Classroom: The Democratic Power of Discussion. New York, NY: Routledge.

Hess, D. \& Zola, J. (2012). Professional Development as a Tool for Improving Civic Education. In Campbell, D., Hess, F. \& Levinson, M., Eds. (2012). Making Civics Count: Citizenship Education for a New Generation. Cambridge, MA: Harvard Education Press.

Higher Education Statistics Agency. 2011. International Baccalaureate Students Studying at UK Higher Education Institutions. http://www.ibo.org/research/policy/programmevalidation/diploma/.

Hirsch, E.D. (1987). Cultural Literacy: What Every American Needs to Know. New York, NY: Random House.

Hooghe, M., and Dietlind, S. (2004). Good Girls Go to the Polling Booth, Bad Boys Go Everywhere: Gender Differences in Anticipated Political Participation Among American Fourteen-Year-Olds. Women and Politics. Vol. 26 (3/4)

International Baccalaureate Organization (2006). Theory of Knowledge Diploma Programme Guide. Cardiff, Wales: International Baccalaureate Organization.

International Baccalaureate Organization (2007). Economics course overview. Cardiff, Wales: International Baccalaureate Organization.

International Baccalaureate Organization (2008a). IB Learner Profile Booklet. Cardiff: Wales. Cardiff, Wales: International Baccalaureate Organization. Retrieved from http://www.ibo.org/programmes/profile/

International Baccalaureate Organization (2008b). Creativity, Action and Service Guide. Cardiff, Wales: International Baccalaureate Organization.

International Baccalaureate Organization. (2009a). The Diploma Programme: A Basis for Practice. Cardiff, Wales: International Baccalaureate Organization.

International Baccalaureate Organization. (2009b). History course overview. Cardiff, Wales: International Baccalaureate Organization.

International Baccalaureate Organization. (2009c). CAS overview. Cardiff, Wales: International Baccalaureate Organization.

International Baccalaureate Organization. (2010). Information Global Society overview. Cardiff, Wales: International Baccalaureate Organization.

International Baccalaureate Organization. (2012). Handbook of Procedures for the IB Diploma Program. Cardiff, Wales: International Baccalaureate Organization. 
International Baccalaureate Organization. (2013). Examining Academic CivicMindedness and Citizenship in the International Baccalaureate Diploma Programme. Unpublished Request for Proposals.

Jefferson, T. (1856). Report of the Commissioners Appointed to Fix the Site of the University of Virginia. In Early History of the University of Virginia, as Contained in the Letters of Thomas Jefferson and Joseph Cabell. Richmond, VA: J.W. Randolph.

Kahne, J., Middaugh, E. \& Croddy, M. (2005). Educating for Democracy: California Campaign for the Civic Mission of Schools California Survey of Civic Education. Los Angeles, CA: The Constitutional Rights Foundation. Retrieved from: http://www.civicsurvey.org/sites/default/files/publications/civic_survey_final.pdf

Kahne, J., \& Middaugh, E. (2008). High quality civic education: What is it and who gets it? Social Education, 72(1), 34-39.

Kahne, J. E., \& Sporte, S. E. (2008). Developing citizens: The impact of civic learning opportunities on students' commitment to civic participation. American Educational Research Journal, 45(3), 738-766.

Keeter, S., Zukin, C., Andolina, M., \& Jenkins, K. (2002). The civic and political health of the nation: A generational portrait. Medford, MA: Center for Information and Research on Civic Learning and Engagement (CIRCLE).

Kulundu, F., \& Hayden, M. (2002). Creativity, action, service (CAS) activities as part of the International Baccalaureate Diploma Programme: A case study. Pastoral Care in Education, 20(1), 30.

Levine, P. (2012). Education for a Civil Society. In Campbell, D., Hess, F. \& Levinson, M., Eds. (2012). Making Civics Count: Citizenship Education for a New Generation. Cambridge, MA: Harvard Education Press.

Levinson, M. (2012a). Diversity and Civic Education. In Campbell, D., Hess, F. \& Levinson, M., Eds. (2012). Making Civics Count: Citizenship Education for a New Generation. Cambridge, MA: Harvard Education Press.

Levinson (2012b). No Citizen Left Behind. Cambridge, MA: Harvard University Press.

Mann, H. (1891). Life and Works of Horace Mann Volume 4. Boston, MA: Lee and Shepard.

Marshall, C. \& Rossman, G. (2006). Designing Qualitative Research. Thousand Oaks, CA: Sage Publications.

Mathews, J., \& Hill, I. (2005). Supertest : How the International Baccalaureate Can Strengthen Our Schools. Chicago, IL: Open Court. 
Miles. M. \& Huberman, M. (1994). Qualitative Data Analysis. Thousand Oaks, CA: Sage Publications.

National Center for Education Statistics. (Undated). National Assessments of Educational Progress $201012^{\text {th }}$ grade civics database. Retrieved from http://nces.ed.gov/nationsreportcard/naepdata/dataset.aspx

National Center for Education Statistics. (Undated). Common Core of Data for 20102011. Retrieved from https://nces.ed.gov/ccd/schoolsearch/

Niemi, R. (2012). What Studnts Know About Civics and Government. In Campbell, D., Hess, F. \& Levinson, M., Eds. (2012). Making Civics Count: Citizenship Education for a New Generation. Cambridge, MA: Harvard Education Press.

Norman H. Nie, Jane Junn, and Kenneth Stehlik-Barry (1996). Education and Democratic Citizenship in America. Chicago: University of Chicago Press: 1-20.

Perkins, D. (forthcoming). Educating for the Unknown. San Francisco, CA: Jossey-Bass.

Putnam, R. D. (2000). Bowling alone: The collapse and revival of American community. New York: Simon and Schuster.

Ravitch, D. \& Viteritti, J.P. eds. (2001). Making Good Citizens: Education and Civil Society. New Haven: Yale University Press.

Reuben, J. (2005) "Patriotic Purposes: Public Schools and the Education of Citizens." In Susan Fuhrman and Marvin Lazerson, eds., The Public Schools. Oxford: Oxford University Press.

Saavedra, A.R. (2014). The Academic Impact of Enrollment in International Baccalaureate Diploma Programs: A Case Study of Chicago Public Schools. Teachers College Record 116 (4)

Saavedra, A.R, \& Opfer, V.D. (2012). Teaching and Learning $21^{\text {st }}$ Century Skills: Lessons from the Learning Sciences. New York, NY: The Asia Society.

Siskin, L. S., \& Weinstein, M. (2008). Supplemental survey to: Creating support structures and services for Title 1 high schools implementing the International Baccalaureate programs. New York University, New York: Institute for Education and Social Policy.

Tabachnick, B. \& Fidell, L. (2001). Using Multivariate Statistics. Boston, MA: Pearson Allyn \& Bacon.

Torney-Purta, J., Amadeo, J. \& Richardson, W. (2007). Civic service among youth in Chile, Denmark, England and the United States: A psychological perspective. In M. 
Sherraden \& A. McBride (Eds.). Civic service worldwide: Impacts and inquiries. Armonk, N.Y: M.E. Sharpe. (pp. 95-132)

U.S. Department of Agriculture (2012). Eligibility Manual for School Meals: Determining and Verifying Eligibility. Washington DC: Child Nutrition Programs, Food and Nutrition Service. Retrieved from http://www.fns.usda.gov/cnd/lunch/

U.S. Department of Education. (2011). A blueprint for reform: The Reauthorization of the Elementary and Secondary Education Act. Alexandria: VA: EdPubs. Retrieved (January 17) from http://www2.ed.gov/policy/elsec/leg/blueprint/blueprint.pdf

U.S. Census, 2011. 2010 Census shows U.S. diversity. Retrieved from http://www.census.gov/newsroom/releases/archives/2010_census/cb11-cn125.html

Wagner, T. (2008). The global achievement gap: Why even our best schools don't teach the new survival skills our children need - and what we can do about it. New York, NY: Basic Books.

Westheimer, J. \& Kahne, J. (2004). What Kind of Citizen? The Politics of Educating for Democracy American Educational Research Journal. Vol 41(2), Sum 2004, pp. 237269. 


\section{Tables}

Table 1: Sample school characteristics $(n=4)$.

\begin{tabular}{cccc}
\hline School ID & $\begin{array}{c}\text { Approximate } \\
\text { percent Free/reduced- } \\
\text { lunch eligible }\end{array}$ & $\begin{array}{c}\text { Approximate 2012 } \\
\text { Base Academic } \\
\text { Performance Index }\end{array}$ & $\begin{array}{c}\text { Length of IB World } \\
\text { School authorization }\end{array}$ \\
\hline 1 & 66 & 746 & 27 years \\
2 & 50 & 829 & 16 years \\
3 & 38 & 873 & 3 years \\
4 & 13 & 879 & 18 years \\
\hline
\end{tabular}


Table 2: Student survey construct details.

\begin{tabular}{|c|c|c|c|c|}
\hline Construct & Source & Item list & $\begin{array}{l}\text { Flanagan et } \\
\text { al (2007) } \\
\text { internal } \\
\text { consistency }\end{array}$ & $\begin{array}{l}\text { IB sample } \\
\text { internal } \\
\text { consistency }\end{array}$ \\
\hline Civic skills & $\begin{array}{l}\text { California Survey } \\
\text { of Civic } \\
\text { Education } \\
\text { (Kahne, } \\
\text { Middaugh \& } \\
\text { Coddy, 2005) }\end{array}$ & $\begin{array}{l}\text { If you found out about a problem in your community that you wanted to do } \\
\text { something about (for example, high levels of lead were discovered in the } \\
\text { local drinking water), how well do you think you would be able to do each of } \\
\text { the following (I definitely can't, I probably can't, I probably can or I } \\
\text { definitely can)? } \\
\text { - Create a plan to address the problem. } \\
\text { - Get other people to care about the problem. } \\
\text { - Organize and run a meeting. } \\
\text { - Express your views in front of a group of people. } \\
\text { - Identify individuals or groups who could help you with the problem. } \\
\text { - Call someone on the phone that you have never met before to get } \\
\text { - their help with solving the problem. } \\
\text { - Contact an elected official about the problem. }\end{array}$ & 0.90 & 0.79 \\
\hline $\begin{array}{l}\text { Civic } \\
\text { knowledge }\end{array}$ & $\begin{array}{l}\text { Center for } \\
\text { Information and } \\
\text { Research on } \\
\text { Civic Learning } \\
\text { and Engagement }\end{array}$ & $\begin{array}{l}\text { - Does the U.S. federal government spend more on Social Security or } \\
\text { foreign aid? } \\
\text { - Which U.S. political party is more conservative? } \\
\text { - How much of a majority is required for the U.S. Senate and House to } \\
\text { override a Presidential veto? }\end{array}$ & $\begin{array}{l}\text { Not } \\
\text { applicable }\end{array}$ & $\begin{array}{l}\text { Not } \\
\text { applicable }\end{array}$ \\
\hline
\end{tabular}




\begin{tabular}{|c|c|c|c|c|}
\hline & $\begin{array}{l}\text { (CIRCLE)'s } 2012 \\
\text { youth voting } \\
\text { survey }\end{array}$ & $\begin{array}{l}\text { - Which of the following best describes who is entitled to vote in } \\
\text { federal elections? }\end{array}$ & & \\
\hline $\begin{array}{l}\text { Civic } \\
\text { knowledge }\end{array}$ & $\begin{array}{l}\text { The National } \\
\text { Assessment of } \\
\text { Education } \\
\text { Progress (NAEP) } \\
2010 \text { twelfth } \\
\text { grade civics } \\
\text { assessment }\end{array}$ & $\begin{array}{l}\text { The NAEP items require students to draw from their civic knowledge to: } \\
\text { - Identify a violation of the Fifth Amendment } \\
\text { - Know that the Constitution does not describe Presidential budget } \\
\text { responsibilities } \\
\text { - Understand the circumstances of the Fourteenth Amendment } \\
\text { - Understand the argument for the positive role that lobbyists can play } \\
\text { in U.S. politics } \\
\text { - Identify an argument used by critics of the Articles of Confederation } \\
\text { - Identify how the federal system encourages the growth of interest } \\
\text { groups }\end{array}$ & $\begin{array}{l}\text { Not } \\
\text { applicable }\end{array}$ & $\begin{array}{l}\text { Not } \\
\text { applicable }\end{array}$ \\
\hline $\begin{array}{l}\text { Citizenship } \\
\text { orientation: } \\
\text { Participatory }\end{array}$ & $\begin{array}{l}\text { Westheimer \& } \\
\text { Kahne, } 2004\end{array}$ & $\begin{array}{l}\text { Please indicate your agreement with the following statements (Strongly } \\
\text { Disagree, Disagree, Slightly Disagree, Slightly Agree, Agree, Strongly } \\
\text { Agree): } \\
\text { - Being actively involved in state and local issues is my responsibility } \\
\text { - Being concerned with national, state and local issues is an important } \\
\text { responsibility for everybody. } \\
\text { - Everyone should be involved in working with community organizations } \\
\text { and local government on issues that affect the community } \\
\text { - I think it is important to be involved in improving my community. }\end{array}$ & 0.82 & 0.90 \\
\hline $\begin{array}{l}\text { Citizenship } \\
\text { orientation: }\end{array}$ & $\begin{array}{l}\text { Westheimer \& } \\
\text { Kahne, } 2004\end{array}$ & $\begin{array}{l}\text { - I think people should assist those in their lives who are most in need of } \\
\text { help. }\end{array}$ & 0.89 & 0.83 \\
\hline
\end{tabular}


Personally

responsible

Citizenship orientation:

Social justice
- I think it's important for people to follow the rules and laws.

- I try to help when I see people in need.

- I am willing to help others without being paid.

- I feel personally responsible for keeping the community clean and safe.

- I try to be kind to other people.

- I think it's important to tell the truth.
Westheimer \&

Kahne, 2004
- I think it's important to challenge inequalities in society.

- I think it's important to think critically about laws and government.

- I think it's important to protest when something in society needs changing.

- When thinking about problems in society, it is important to focus on the underlying causes.

- I think it's important to buy products from socially responsible businesses.

I think it's important to work for positive social change. 
Table 3: IB students' demographic characteristics and family backgrounds $(n=24)$.

\begin{tabular}{|c|c|c|}
\hline & Frequency & Percent \\
\hline \multicolumn{3}{|l|}{ Gender } \\
\hline Male & 9 & 38 \\
\hline Female & 15 & 63 \\
\hline \multicolumn{3}{|l|}{$\underline{\text { Race }}$} \\
\hline White & 2 & 8 \\
\hline Black & 2 & 8 \\
\hline Hispanic & 8 & 33 \\
\hline Asian & 12 & 50 \\
\hline \multicolumn{3}{|l|}{ Mother's Educational Attainment } \\
\hline Some high school & 3 & 13 \\
\hline High school graduate & 0 & 0 \\
\hline Some college & 6 & 25 \\
\hline 4-year college graduate & 9 & 38 \\
\hline Masters & 6 & 25 \\
\hline $\mathrm{PhD}$ & 0 & 0 \\
\hline \multicolumn{3}{|l|}{ Parental birthplace } \\
\hline Mother born outside the U.S. & 3 & 13 \\
\hline Father born outside the U.S. & 2 & 8 \\
\hline Both parents born outside the U.S. & 13 & 54 \\
\hline Both were born in the U.S. & 5 & 21 \\
\hline Missing & 1 & 4 \\
\hline$\underline{\operatorname{Age}(n=21)}$ & $\begin{array}{c}\text { Mean }=17.3 \\
(\mathrm{SD}=0.6)\end{array}$ & \\
\hline
\end{tabular}

Notes: Due to rounding, percentages can equal greater than 100 per cent. One of the students identified as half-Hispanic, half-White and is categorized as Hispanic. 
Table 4: By school, frequencies of teachers' perceptions of IB and non-IB students' socioeconomic and academic backgrounds $(n=15)$.

\begin{tabular}{ccccccccc}
\hline \multicolumn{4}{c}{ Socio-economic difference } & \multicolumn{5}{c}{ Academic difference } \\
\hline & Higher & Same & Lower & & Higher & Same & Lower & \\
School & SES in & SES in & SES in & Don't & in IB & in IB & in IB & No \\
& IB than & IB and & IB than & Know & than & and & than & Response \\
& non-IB & non-IB & non-IB & & non-IB & non-IB & non-IB & \\
\hline 1 & & 2 & & 1 & 3 & & \\
2 & & 3 & & & 3 & & \\
3 & $2 *$ & 3 & & 1 & 4 & 2 & & 1 \\
4 & 1 & 2 & & & 2 & & & 1 \\
\hline
\end{tabular}

* These two teachers indicated that socio-economic differences between IB and non-IB differs by grade; for $11^{\text {th }}$ grade, the SES status is the same and $12^{\text {th }}$ grade, the SES status is higher for IB than non-IB. 
Table 5: IB students' educational backgrounds and aspirations $(n=24)$.

\begin{tabular}{lcc}
\hline & Frequency & Percent \\
\hline Pre-IB DP preparation & 5 & 21 \\
Middle Years Programme (MYP) only & 1 & 4 \\
Both PYP and MYP & 3 & 13 \\
A non-MYP 9th and 10th grade IB DP & 12 & 50 \\
prep & 3 & 13 \\
No formal IB DP prep & & \\
Missing & 23 & 96 \\
Intention to enroll in college next year & 0 & 0 \\
4-year & 1 & 4 \\
No & & \\
Undecided & 4 & 17 \\
Frequency of political discussion with parents & 7 & 29 \\
Daily & 3 & 13 \\
1-3 times per week & 5 & 21 \\
1-3 times per month & 5 & 21 \\
Occasionally & Mean=4.1 \\
Never & (S.D.=0.5) \\
GPA (n=21) & \\
\hline
\end{tabular}

Notes: Due to rounding, percentages can equal greater than 100 per cent. 
Table 6: Students views on civic education "best practices" $(n=24)$.

\begin{tabular}{|c|c|c|c|c|c|c|}
\hline & $\begin{array}{l}\text { Almost } \\
\text { every } \\
\text { day } \\
\%(\#)\end{array}$ & $\begin{array}{l}1-2 \\
\text { times } \\
\text { week } \\
\%(\#)\end{array}$ & $\begin{array}{l}\text { Once or } \\
\text { twice a } \\
\text { month } \\
\%(\#)\end{array}$ & $\begin{array}{c}\text { A } \\
\text { few } \\
\text { times } \\
\text { a year } \\
\%(\#)\end{array}$ & $\begin{array}{l}\text { Never } \\
\%(\#)\end{array}$ & $\begin{array}{l}\text { Missing } \\
\%(\#)\end{array}$ \\
\hline \multicolumn{7}{|l|}{ NAEP (Percentages only) } \\
\hline *Discussion of current events & 30 & 32 & 19 & 10 & 8 & 0 \\
\hline *Debates or panel discussions & 8 & 16 & 23 & 22 & 31 & 0 \\
\hline *Role-playing, mock trials or dramas & 3 & 4 & 12 & 26 & 55 & 0 \\
\hline $\begin{array}{l}\text { *Write a letter to share an opinion or } \\
\text { help solve a problem }\end{array}$ & 1 & 3 & 7 & 20 & 70 & 0 \\
\hline \multicolumn{7}{|l|}{$\begin{array}{l}\text { Through the IB DP including DP- } \\
\text { related extracurricular activities: }\end{array}$} \\
\hline *Discussion of current events & $58(14)$ & $38(9)$ & $0(0)$ & $4(1)$ & $0(0)$ & $0(0)$ \\
\hline *Debates & $38(9)$ & $33(8)$ & $21(5)$ & $4(1)$ & $4(1)$ & $0(0)$ \\
\hline *Simulations & $8(2)$ & $29(7)$ & $33(8)$ & $21(5)$ & $8(2)$ & $0(0)$ \\
\hline $\begin{array}{l}\text { *Write a letter to share an opinion or } \\
\text { help solve a problem } \\
\text { Informally with your IB DP peers: }\end{array}$ & $4(1)$ & $4(1)$ & $13(3)$ & $29(7)$ & $46(11)$ & $4(1)$ \\
\hline *Discussion of current events & $50(12)$ & $33(8)$ & $8(2)$ & $8(2)$ & $0(0)$ & $0(0)$ \\
\hline$*$ Debates & $63(15)$ & $29(7)$ & $0(0)$ & $4(1)$ & $4(1)$ & $0(0)$ \\
\hline *Simulations & $8(2)$ & $29(7)$ & $17(4)$ & $13(3)$ & $33(8)$ & $0(0)$ \\
\hline $\begin{array}{l}\text { *Write a letter to share an opinion or } \\
\text { help solve a problem }\end{array}$ & $0(0)$ & $8(2)$ & $8(2)$ & $8(2)$ & $75(18)$ & $0(0)$ \\
\hline \multicolumn{7}{|l|}{ Through non-IB DP courses and } \\
\hline *Discussion of current events & $4(1)$ & $21(5)$ & $33(8)$ & $8(2)$ & $29(7)$ & $4(1)$ \\
\hline *Debates & $8(2)$ & $8(2)$ & $17(4)$ & $13(3)$ & $50(12)$ & $4(1)$ \\
\hline *Simulations & $4(1)$ & $0(0)$ & $17(4)$ & $25(6)$ & $50(12)$ & $4(1)$ \\
\hline $\begin{array}{l}\text { *Write a letter to share an opinion or } \\
\text { help solve a problem }\end{array}$ & $0(0)$ & $0(0)$ & $8(2)$ & $8(2)$ & $79(19)$ & $4(1)$ \\
\hline \multicolumn{7}{|l|}{ Informally with your non-IB DP peers: } \\
\hline *Discussion of current events & $25(6)$ & $21(5)$ & $38(9)$ & $0(0)$ & $13(3)$ & $4(1)$ \\
\hline *Debates & $17(4)$ & $17(4)$ & $29(7)$ & $8(2)$ & $25(6)$ & $4(1)$ \\
\hline *Simulations & $4(1)$ & $4(1)$ & $17(4)$ & $8(2)$ & $63(15)$ & $4(1)$ \\
\hline $\begin{array}{l}\text { *Write a letter to share an opinion or } \\
\text { help solve a problem }\end{array}$ & $0(0)$ & $0(0)$ & $8(2)$ & $8(2)$ & $79(19)$ & $4(1)$ \\
\hline
\end{tabular}


Table 7: Comparisons of student knowledge with NAEP and CIRCLE samples (\% correct)

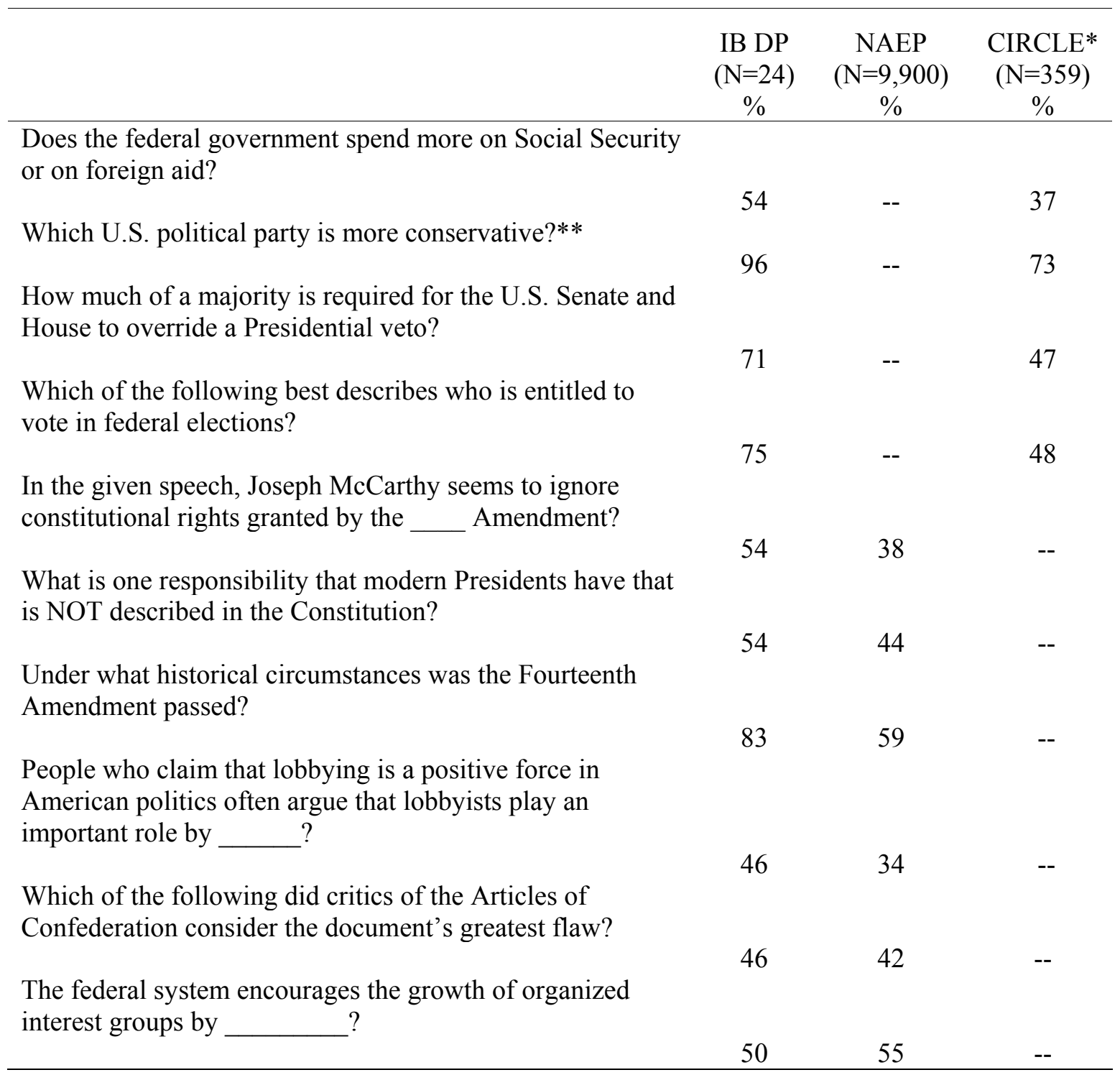

*CIRCLE responses were from students who were 18 years old and either currently enrolled in high school or had graduated from high school for appropriate comparison with IB DP students (who have an average age of 17.29).

**This question was asked slightly differently on the CIRCLE survey, which simply asked if one political party was more conservative than the other 
Table 8: Student self-assessment of skills related to civic engagement $(n=24)$.

\begin{tabular}{|c|c|c|c|c|c|}
\hline & $\begin{array}{c}\text { I } \\
\text { definitely } \\
\text { can't } \\
\%(\#)\end{array}$ & $\begin{array}{c}\text { I } \\
\text { probably } \\
\text { can't } \\
\%(\#)\end{array}$ & $\begin{array}{c}\text { I } \\
\text { probably } \\
\text { can } \\
\%(\#)\end{array}$ & $\begin{array}{c}\text { I } \\
\text { definitely } \\
\text { can } \\
\%(\#)\end{array}$ & $\begin{array}{c}\text { Missing } \\
\%(\#)\end{array}$ \\
\hline $\begin{array}{l}\text { Create a plan to address the } \\
\text { problem. }\end{array}$ & $0(0)$ & $13(3)$ & $63(15)$ & $25(6)$ & $0(0)$ \\
\hline $\begin{array}{l}\text { Get other people to care about the } \\
\text { problem. }\end{array}$ & $0(0)$ & $8(2)$ & $71(17)$ & $21(5)$ & $0(0)$ \\
\hline Organize and run a meeting. & $4(1)$ & $13(3)$ & $46(11)$ & $38(9)$ & $0(0)$ \\
\hline $\begin{array}{l}\text { Express your views in front of a } \\
\text { group of people. }\end{array}$ & $0(0)$ & $4(1)$ & $13(3)$ & 79 (19) & $4(1)$ \\
\hline $\begin{array}{l}\text { Identify individuals or groups } \\
\text { who could help you with the } \\
\text { problem. }\end{array}$ & $0(0)$ & $8(2)$ & $58(14)$ & $33(8)$ & $0(0)$ \\
\hline $\begin{array}{l}\text { Call someone on the phone that } \\
\text { you have never met before to get } \\
\text { their help with solving the } \\
\text { problem. }\end{array}$ & $4(1)$ & $17(4)$ & $25(6)$ & $54(13)$ & $0(0)$ \\
\hline $\begin{array}{l}\text { Contact an elected official about } \\
\text { the problem. }\end{array}$ & $0(0)$ & $29(7)$ & $54(13)$ & $17(4)$ & $0(0)$ \\
\hline Organize a petition. & $0(0)$ & $25(6)$ & $50(12)$ & $25(6)$ & $0(0)$ \\
\hline
\end{tabular}


Table 9: Student reports of source of knowledge, skills and attitudes addressed in the student survey $(n=24)$.

\begin{tabular}{lccc}
\hline & $\begin{array}{c}\text { Knowledge } \\
\%(\#)\end{array}$ & $\begin{array}{c}\text { Skills } \\
\%(\#)\end{array}$ & $\begin{array}{c}\text { Attitudes } \\
\%(\#)\end{array}$ \\
\hline $\begin{array}{l}\text { Through IB DP including DP-related } \\
\text { extracurricular activities }\end{array}$ & $67(16)$ & $46(11)$ & $25(6)$ \\
$\begin{array}{l}\text { Through non-IB DP courses or extracurricular } \\
\text { activities }\end{array}$ & $17(4)$ & $33(8)$ & $21(5)$ \\
From non-school sources & $13(3)$ & $13(3)$ & $46(11)$ \\
I don't know/No response & $4(1)$ & $8(2)$ & $8(2)$ \\
\hline
\end{tabular}


Table 10: Students' self-reported citizenship orientation $(n=24)$.

\begin{tabular}{|c|c|c|c|c|c|c|c|}
\hline & $\begin{array}{l}\text { Strongly } \\
\text { Agree } \\
\%(\#)\end{array}$ & $\begin{array}{l}\text { Agree } \\
\%(\#)\end{array}$ & $\begin{array}{l}\text { Somewhat } \\
\text { Agree } \\
\%(\#)\end{array}$ & $\begin{array}{l}\text { Somewhat } \\
\text { Disagree } \\
\%(\#)\end{array}$ & $\begin{array}{l}\text { Disagree } \\
\%(\#)\end{array}$ & $\begin{array}{l}\text { Strongly } \\
\text { Disagree } \\
\%(\#)\end{array}$ & $\begin{array}{c}\text { Missing } \\
\%(\#)\end{array}$ \\
\hline \multicolumn{8}{|l|}{ Justice-Oriented Citizen } \\
\hline $\begin{array}{l}\text { *I think it's important to challenge } \\
\text { inequalities in society. }\end{array}$ & $50(12)$ & $33(8)$ & $13(3)$ & $0(0)$ & $4(1)$ & $0(0)$ & $0(0)$ \\
\hline $\begin{array}{l}\text { *I think it's important to think critically about } \\
\text { laws and government. }\end{array}$ & $58(14)$ & $29(7)$ & $13(3)$ & $0(0)$ & $0(0)$ & $0(0)$ & $0(0)$ \\
\hline $\begin{array}{l}\text { *I think it's important to protest when } \\
\text { something in society needs changing. }\end{array}$ & $38(9)$ & $33(8)$ & $25(6)$ & $0(0)$ & $0(0)$ & $0(0)$ & $4(1)$ \\
\hline $\begin{array}{l}\text { *When thinking about problems in society, it } \\
\text { is important to focus on the underlying } \\
\text { causes. }\end{array}$ & $50(12)$ & $42(10)$ & $8(2)$ & $0(0)$ & $0(0)$ & $0(0)$ & $0(0)$ \\
\hline $\begin{array}{l}\text { *I think it's important to buy products from } \\
\text { socially responsible businesses. }\end{array}$ & $13(3)$ & $46(11)$ & $25(6)$ & $4(1)$ & $13(3)$ & $0(0)$ & $0(0)$ \\
\hline \multicolumn{7}{|l|}{$\underline{\text { Participatory Citizen }}$} & $0(0)$ \\
\hline $\begin{array}{l}\text { *Being actively involved in state and local } \\
\text { issues is my responsibility. }\end{array}$ & $21(5)$ & $8(2)$ & $58(14)$ & $0(0)$ & $4(1)$ & $4(1)$ & $4(1)$ \\
\hline $\begin{array}{l}\text { *Being concerned with national, state and } \\
\text { local issues is an important responsibility for } \\
\text { everybody. } \\
\text { *Everyone should be involved in working } \\
\text { with community organizations and local } \\
\text { government on issues that affect the } \\
\text { community. }\end{array}$ & $25(6)$ & $33(8)$ & $33(8)$ & $4(1)$ & $0(0)$ & $4(1)$ & $0(0)$ \\
\hline
\end{tabular}


*I think it is important to be involved in improving my community.

\section{Personally Responsible Citizen/Person}

*I think people should assist those in their lives who are most in need of help.

*I think it's important for people to follow the rules and laws.

*I try to help when I see people in need.

*I am willing to help others without being paid.

\begin{tabular}{ccccccc}
$50(12)$ & $42(10)$ & $4(1)$ & $0(0)$ & $4(1)$ & $0(0)$ & $0(0)$ \\
& & & & & \\
$29(7)$ & $33(8)$ & $33(8)$ & $4(1)$ & $0(0)$ & $0(0)$ & $0(0)$ \\
$17(4)$ & $29(7)$ & $46(11)$ & $4(1)$ & $0(0)$ & $0(0)$ & $4(1)$ \\
$46(11)$ & $42(10)$ & $8(2)$ & $0(0)$ & $4(1)$ & $0(0)$ & $0(0)$ \\
$46(11)$ & $38(9)$ & $17(4)$ & $0(0)$ & $0(0)$ & $0(0)$ & $0(0)$ \\
$13(3)$ & $33(8)$ & $42(10)$ & $8(2)$ & $0(0)$ & $4(1)$ & $0(0)$ \\
$38(9)$ & $42(10)$ & $21(5)$ & $0(0)$ & $0(0)$ & $0(0)$ & $0(0)$ \\
$33(8)$ & $33(8)$ & $29(7)$ & $0(0)$ & $4(1)$ & $0(0)$ & $0(0)$ \\
\hline
\end{tabular}





\section{Appendix A: Student interview protocol}

[Informed consent language]

I am interested in learning about your experiences as a student in the IB Diploma Program (DP) at [SCHOOL NAME]. Specifically, I would like to ask you about your perceptions of the extent to which the IB DP promotes' students civic knowledge, skills and attitudes and through what means.

The idea of citizenship is one that means different things to different people. For example, some people equate citizenship with voting, others with recycling, others with following laws and rules, others with fighting for individual rights and others with issues of legal documentation. To avoid a situation in which I need to define citizenship for you:

1. Think about a social problem that is important to you. Briefly,

a. What is your perspective on the nature, causes and possible ways of addressing the problem?

b. What knowledge, skills and attitudes are necessary to address the problem?

2. What sorts of experiences (inside or outside of school) do students need to develop such knowledge, skills and attitudes? [Prompt: For example, certain courses, extracurricular activities, mentorship from role models, informal discussions with peers]

3. Do you feel that your IB DP teachers attempt to help you to develop this knowledge?

a. Through the curriculum? If so, please provide an example. [Prompt: certain coursework, EE research]

b. Through the way they teach and manage their classrooms? If so, please provide an example. [Prompt: For example, through lecture, through discussion that requires knowledge, through research-related activities]

c. Which aspects of the IB DP do you feel contribute the most and least to developing this knowledge? [Prompt: For example, CAS, EE, TOK, elective subjects, informal discussions with IB DP peers]

4. Do you feel that your IB DP teachers attempt to help you to develop these skills?

a. Through curriculum? If so, please provide an example. [Prompt: certain coursework, CAS activities, TOK activities]

b. Through the way they teach and how they manage their classrooms? If so, please provide an example. [Prompt: For example, through group work, 
practicing skills like public speaking or writing to the newspaper]

c. Which aspects of the IB DP do you feel contribute the most and least to developing these skills? [Prompt: For example, CAS, EE, TOK, elective subjects, informal discussions with IB DP peers]

5. Do you feel that your IB DP teachers attempt to help you to develop these attitudes?

a. Through curriculum? If so, please provide an example. [Prompt: certain coursework, CAS activities, TOK activities, EE activities]

b. Through the way they teach and manage their classrooms? [Prompt: For example, through their enthusiasm, through providing rationales for civic engagement]

c. Which aspects of the IB DP do you feel contribute the most and least to developing these attitudes? [Prompt: For example, CAS, EE, TOK, elective subjects, informal discussions with IB DP peers]

6. How would you compare IB DP (including coursework, extracurricular activities and interaction with IB DP peers) development of the types of knowledge, skills and attitudes we have been discussing with non-IB DP (again including coursework, extracurricular activities and interaction with IB DP peers) development of the same knowledge, skills and attitudes?

7. Is there anything else you'd like to add that we have not already discussed about IB DP development of citizenship and civic knowledge 


\section{Appendix B: Teacher interview protocol}

[Informed consent language]

I am interested in learning about your experiences working with the IB Diploma Program (DP) at [SCHOOL NAME]. Specifically, I would like to ask you about your perceptions of the extent to which the IB DP promotes' students civic knowledge, skills and attitudes and through what means.

1. What courses do you teach, including International Baccalaureate Diploma Programme (IB DP) and non IB DP courses?

2. Please could you describe your level of experience with the IB DP_-including as a teacher or administrator-at your current school? At other schools?

3. How would you describe the socio-economic status of the majority of your IB DP students? Non IB DP students?

4. How would you describe the academic background of the majority of your IB DP students? Non IB DP students?

5. Some people argue that, in addition to preparing students for college and career, public schools should develop students as citizens. Do you agree with this? If so, why do you believe that development of citizenship is important?

The idea of citizenship is one that means different things to different people. For example, some people equate citizenship with voting, others with recycling, others with following laws and rules, others with fighting for individual rights and others with issues of legal documentation. To avoid a situation in which I need to define citizenship for you:

6. Please think about a social problem your students are concerned about. Briefly,

a. What is your perspective on the nature, causes and possible ways of addressing the problem?

b. What knowledge, skills and attitudes are necessary to address the problem?

7. Do you attempt to help you to develop this knowledge in IB DP students? If so, how (please provide examples)?

a. Through the curriculum? [Prompt: certain coursework, EE research]

b. Through pedagogy and classroom management? [Prompt: For example, 
through lecture, through discussion that requires knowledge, through research-related activities]

c. Which aspects of the IB DP do you feel contribute the most and least to developing this knowledge? [Prompt: For example, CAS, EE, TOK, elective subjects, informal discussions with IB DP peers]

8. Do you attempt to help you to develop these skills in IB DP students? If so, how (please provide examples)?

a. Through curriculum? [Prompt: certain coursework, CAS, TOK]

b. Through pedagogy and classroom management? [Prompt: For example, through group work, practicing skills like public speaking or writing to the newspaper]

c. Which aspects of the IB DP do you feel contribute the most and least to developing these skills? [Prompt: For example, CAS, EE, TOK, elective subjects, informal discussions with IB DP peers]

9. Do you attempt to help you to develop these attitudes in IB DP students? If so, how (please provide examples)?

a. Through curriculum? [Prompt: certain coursework, CAS activities, TOK activities, EE activities]

b. Through pedagogy and classroom management? [Prompt: For example, through their enthusiasm, through providing rationales for civic engagement]

c. Which aspects of the IB DP do you feel contribute the most and least to developing these attitudes? [Prompt: For example, CAS, EE, TOK, elective subjects, informal discussions with IB DP peers]

10. How would you compare development of this knowledge, skills and attitudes with IB compared to non-IB DP students? Please provide specific.

a. Through curriculum

b. Through pedagogy and classroom management

11. What are the main barriers to striving to develop your IB students' citizenship/civic-related knowledge, skills and attitudes?

12. Is there anything else you'd like to add about development of citizenship and civic knowledge, skills and attitudes through the IB DP? 


\section{Appendix C: Student survey}

\section{Introduction}

The purpose of the research is to increase knowledge of the relationship between IB DP enrollment and students' civic knowledge, skills and attitudes. The survey should take no longer than 15 minutes to complete. Although the survey is voluntary, your input is very important to the study. There are no obvious risks or benefits to participation in this survey. You can choose not to answer specific questions. Your individual responses will be kept strictly confidential; all information will be used for research purposes only. Individual information will not be released to your school or IB. Your responses will be combined with the responses of other students and reported in the aggregate. Aggregate responses will be used to contribute to the ongoing improvement of the IB DP.

Items included in the survey have been adapted from the following sources:

CIRCLE (2013). All Together Now: Collaboration and Innovation for Youth Engagement: The Report of the Commission on Youth Voting and Civic Knowledge. Medford, MA: Center for Information \& Research on Civic Learning and Engagement.

Kahne, J., Middaugh, E., \& Coddy, M. (2005). California Civic Index. New York: Carnegie Corporation and Annenberg Foundation.

National Assessment of Educational Progress. (2010). 12th grade Civics Assessment, publicly-available items.

Westheimer, J. \& Kahne, J. (2004). What Kind of Citizen? The Politics of Educating for Democracy American Educational Research Journal. Vol 41(2), Sum 2004, pp. 237- 269.

If you have any questions about this survey, you can contact Anna Saavedra, the Principal Investigator at my email address asaavedr@rand.org or phone 310-393-0411 Extension 6437. If you have any questions or concerns about your rights as a research subject, please contact the Human Subjects Protection Committee at RAND, 1776 Main Street, PO Box 2138, Santa Monica, CA 90407, 310-393-0411, ext. 6124, or by email at Carolyn Tschopik@rand.org.

Thank you for participating and for your support in researching the IB DP.

I have read and understand this information about the survey ( ) [must click to continue]. 
If you found out about a problem in your community that you wanted to do something about (for example, high levels of lead were discovered in the local drinking water), how well do you think you would be able to do each of the following (I definitely can't, I probably can't, I probably can or I definitely can)?

- Create a plan to address the problem

- Get other people to care about the problem

- Organize and run a meeting

- Express your views in front of a group of people

- Identify individuals or groups who could help you with the problem

- Call someone on the phone that you had never met before to get their help with the problem.

- Contact an elected official about the problem.

- Organize a petition.

\section{[Page break]}

Does the federal government spent more on Social Security or on foreign aid?

- Social Security

- Foreign aid

- Same

Which U.S. political party is more conservative?

- Republican

- Democrat

How much of a majority is required for the U.S. Senate and House to override a Presidential veto?

- $67 \%$

- $50 \%$

- $33 \%$

- $25 \%$

Which of the following best describes who is entitled to vote in federal elections?

- Residents

- Taxpayers

- Legal residents

- Citizens 
"A witness' refusal to answer whether or not he is a Communist on the ground that his answer would tend to incriminate him is the most positive proof obtainable that the witness is a Communist." —-Senator Joseph McCarthy, 1953

In the speech above, Joseph McCarthy seems to ignore constitutional rights granted by the

- First Amendment

- Second Amendment

- Fourth Amendment

- Fifth Amendment

What is one responsibility that modern Presidents have that is NOT described in the Constitution?

- Commanding the armed forces

- Proposing an annual budget to Congress

- Appointing Supreme Court justices

- Granting pardons

People who claim that lobbying is a positive force in American politics often argue that lobbyists play an important role by

- Supplying members of Congress with information and helping to draft legislation

- Giving Supreme Court justices information they need to make decisions in difficult cases

- Giving everybody equal power in the political process

- Limiting access to public officials

This question is about the Fourteenth Amendment to the Constitution, an excerpt of which is printed below.

All persons born or naturalized in the United States . . . are citizens of the United States and of the State wherein they reside. No State shall make or enforce any law which shall abridge the privileges or immunities of citizens of the United States; nor shall any State deprive any person of life, liberty, or property, without due process of law; nor deny to any person within its jurisdiction the equal protection of the laws.

Under what historical circumstances was the Fourteenth Amendment passed?

- It was passed soon after the American Revolution to limit the power of the federal government.

- It was passed soon after the Civil War to protect the rights of former slaves. 
- It was passed soon after the First World War to protect the rights of immigrants.

- It was passed during the Vietnam War to protect the freedom of antiwar protesters.

Which of the following did critics of the Articles of Confederation consider the document's greatest flaw?

- There were no provisions to amend the Articles.

- The President had the exclusive right to declare war.

- Each state, regardless of its population, had only one vote in electing the President.

- The national government was too weak for the effective implementation of needed policies.

The federal system encourages the growth of organized interest groups by

- Allowing states to pay part of the operational costs of such groups

- Offering several levels of government where groups can attempt to influence policy

- Giving interest groups free building space in Washington, D.C.

- Encouraging interest groups to take over many of the responsibilities of political parties

\section{[Page break]}

Please indicate your agreement with the following statements (Strongly Disagree, Disagree, Slightly Disagree, Slightly Agree, Agree, Strongly Agree).

[Do not label groupings. The IB DP survey randomized the order of the 17 statements.]

\section{Justice-Oriented Citizen}

- I think it's important to challenge inequalities in society.

- I think it's important to think critically about laws and government.

- I think it's important to protest when something in society needs changing.

- When thinking about problems in society, it is important to focus on the underlying causes.

- I think it's important to buy products from socially responsible businesses.

I think it's important to work for positive social change.

\section{Participatory Citizen}

- Being actively involved in state and local issues is my responsibility

- Being concerned with national, state and local issues is an important responsibility for everybody. 
- Everyone should be involved in working with community organizations and local government on issues that affect the community

- I think it is important to be involved in improving my community.

\section{Personally Responsible Citizen/Person}

- I think people should assist those in their lives who are most in need of help.

- I think it's important for people to follow the rules and laws.

- I try to help when I see people in need.

- I am willing to help others without being paid.

- I feel personally responsible for keeping the community clean and safe.

- I try to be kind to other people.

- I think it's important to tell the truth.

\section{[Page break]}

Through the IB DP including DP-related extracurricular activities, non-IB DP courses, non-IB DP extracurricular activities, informally with your IB DP peers, informally with your non-IB DP peers, how often do you engage in (several times a week, weekly, monthly, rarely, never):

- Discussion of current events

- Debates

- Write a letter to share an opinion or help solve a problem

- Simulation

[Page break]

Please check the one box per row that best describes how you gained most of the knowledge, skills and attitudes addressed in this survey:

\begin{tabular}{|c|c|c|c|c|c|c|}
\hline & $\begin{array}{l}\text { Through the } \\
\text { IB DP } \\
\text { including DP- } \\
\text { related } \\
\text { extracurricular } \\
\text { activities }\end{array}$ & $\begin{array}{l}\text { Through } \\
\text { non-IB } \\
\text { DP } \\
\text { courses }\end{array}$ & $\begin{array}{l}\text { Through non- } \\
\text { IB DP } \\
\text { extracurricular } \\
\text { activities }\end{array}$ & $\begin{array}{l}\text { From } \\
\text { non- } \\
\text { school } \\
\text { sources }\end{array}$ & $\begin{array}{l}\text { I } \\
\text { don't } \\
\text { know }\end{array}$ & $\begin{array}{l}\text { I don't } \\
\text { have the } \\
\text { knowledge, } \\
\text { skills, or } \\
\text { attitudes }\end{array}$ \\
\hline $\begin{array}{l}\text { Knowledge } \\
\text { Skills } \\
\text { Attitudes }\end{array}$ & & & & & & \\
\hline
\end{tabular}

[Page break] 


\section{Demographic}

- Age

- Male/female

- Ethnicity (white, black, Hispanic, Asian, other)

- Mother's and Father's educational attainment (no HS, HS, some college, 4-yr college graduate, masters, $\mathrm{PhD}$ )

- Parents born outside of the U.S. (mother, father, both, neither)

\section{Educational background}

- Intention to enroll in college next year (none, 2-yr, 4-yr)

- Frequency of discussion of political issues with parents (daily, 1-3 times per week, 13 times per month, occasionally, never)

- GPA (ask students approximate GPA)

- IB DP preparation (Primary Years Programme only, Middle Years Programme only, both PYP and MYP, a non-MYP $9^{\text {th }}$ and $10^{\text {th }}$ grade IB DP preparation program, no formal IB DP preparation)

- Survey also includes for each student: student id, school id, date survey completed, school API rank, \% school free/reduced lunch 


\section{Appendix D: Student survey details}

Civic Skills: Familiarity with effective advocacy techniques

To measure students' familiarity with "effective advocacy techniques," a part of the IBO's definition of "academic civic mindedness," I use a scale administered as part of the California Survey of Civic Education (Kahne, Middaugh \& Coddy, 2005). This measure asks students how well they think they would be able to execute a series of eight civic skills in response to a concrete problem in their community including:

- Create a plan to address the problem.

- Get other people to care about the problem.

- Organize and run a meeting.

- Express your views in front of a group of people.

- Identify individuals or groups who could help you with the problem.

- Call someone on the phone that you have never met before to get their help with solving the problem.

- Contact an elected official about the problem.

- Organize a petition.

In their study of the psychometric properties of 17 different scales that measure students' civic outcomes, Flanagan, Syvertson and Stout (2007) define this scale as a measure of students" "competence for civic action" (5). With a sample of 1,924 students, they find an internal consistency of approximately 0.90 . The internal consistency for the student sample in this study is 0.79 .

\section{Civic Knowledge}

The knowledge items included in the survey are from two sources, the Center for Information and Research on Civic Learning and Engagement (CIRCLE)'s 2012 youth voting survey and the National Assessment of Education Progress (NAEP) 2010 twelfth grade civics assessment.

CIRCLE included their knowledge items as part of 15-20 minute telephone surveys administered to a nationally representative sample of 4,483 18 to 24 year olds. The study survey uses the following four multiple-choice items from the CIRCLE survey to assess students' civic knowledge:

- Does the U.S. federal government spend more on Social Security or foreign aid?

- Which U.S. political party is more conservative?

- How much of a majority is required for the U.S. Senate and House to override a Presidential veto? 
- Which of the following best describes who is entitled to vote in federal elections? Access to the CIRCLE data permits comparison of study students' responses to the nationally representative sample.

Students' knowledge of US government and public policy is measured using six publicly-released, multiple-choice NAEP items from the 2010 12th grade civics assessment. The U.S. Department of Education, Institute of Education Sciences, and National Center for Education Statistics collaborated to produce the NAEP Civics Assessment in 2010 for twelfth graders across all national public schools.

The items require students to draw from their civic knowledge to:

- Identify a violation of the Fifth Amendment

- Know that the Constitution does not describe Presidential budget responsibilities

- Understand the circumstances of the Fourteenth Amendment

- Understand the argument for the positive role that lobbyists can play in U.S. politics

- Identify an argument used by critics of the Articles of Confederation

- Identify how the federal system encourages the growth of interest groups I selected these six NAEP items because unlike the majority of released $12^{\text {th }}$ grade NAEP Civics items, they are not obvious tests of reading comprehension-many NAEP items can be answered without prior knowledge through careful reading. I also chose to include in the survey only items rated as Hard (2) or Medium (4) difficulty to maximize the potential to find a noticeable differential between IB students' responses and those of the national population.

The benefits of the NAEP items are that they are valid, reliable, created by experts through a rigorous design process, align considerably to the National Standards for Civics and Government (Center for Civic Education, Calabasas CA 1994) which strongly emphasize constitutional issues and the formal political system (Levine, 2012) and permit comparisons to the national population of twelfth graders.

One of the drawbacks to the NAEP items is that due to the three-year item development process, less than ten percent refer to current events (Niemi, 2012, p. 31). Most civic education experts agree that awareness and discussion of current events is key to promoting civic engagement (e.g., Campbell, Levinson \& Hess, 2012; Hess, 2009) so this limitation is meaningful. Use of the NAEP and CIRCLE items also means that this study does not collect a quantitative measure of students' knowledge of public policy and must rely exclusively on the interviews to assess students' knowledge of U.S. public policy. Another drawback is that NAEP examinations are low-stakes for students, so the national comparison sample may not have strived to answer every item to the best of their ability. However, my student survey was also low-stakes so this concern applies across both surveys. 
The knowledge items were not designed to jointly measure a specific knowledge domain and as expected, the Cronbach's reliability alphas of the CIRCLE (alpha=0.56), NAEP (alpha $=0.40)$ and all knowledge items (alpha $=0.50)$ indicate that they should not be combined into composites.

Citizenship orientation: participatory, personally responsible and social justice

To measure students" "model citizenship" the survey uses three scales that Kahne and co-authors have used to measure students' civic orientations in previous studies (Westheimer \& Kahne, 2004; Kahne, Middaugh \& Coddy, 2005; Kahne \& Sporte, 2008). For their 2004 study Westheimer and Kahne developed sets of items to measure constructs of students' participatory, personally responsible and social justice civic orientation with a likert agreement scale (strongly disagree through strongly agree). Kahne, Middaugh and Coddy (2005) subsequently measured these three constructs with similar items in the 2005 California Survey of Civic Education, which they administered to 2,366 twelfth grade Californian public school students who had completed a U.S. Government course. Kahne \& Sporte (2008) also administered the "participation" items to 4,057 Chicago Public Schools eleventh grade students. The online version of the survey used in the present study randomizes the order of the 17 items for each student in an attempt to rule out the possibility that students could guess how the items "should" fit together and answer correspondingly in a socially desirable way.

Using their sample of 1,924 students, Flangan et al (2007) find that the participatory, personally responsible, and justice-orientation scales have Cronbach's alpha reliability of 0.82, .089 and .081, respectively. For the present study, the alphas are .90, .83 and .79, respectively. These results indicate comparability of this study to prior larger-sample studies and strong internal consistency among individual IB students' responses. 